Open Access

\title{
Economic evaluation of the environmental impact of shipping from the perspective of $\mathrm{CO}_{2}$ emissions
}

\author{
Elyakim Ben-Hakoun ${ }^{1 *}$ (D, Mordechai Shechter ${ }^{2}$ and Yehuda Hayuth ${ }^{3}$
}

\author{
* Correspondence: \\ ebh@tx.technion.ac.il \\ ${ }^{1}$ Faculty of Industrial Engineering \\ and Management, Technion - Israel \\ Institute of Technology, Haifa, Israel \\ Full list of author information is \\ available at the end of the article
}

\begin{abstract}
In this research we evaluate the environmental economic impact of shipping from the perspective of $\mathrm{CO}_{2}$ emissions by implementing Marine Emission Trading Scheme (METS), as defined. This trading scheme is based on the EU Emissions Trading System (EU-ETS) program with adjustments for the shipping industry's needs.

First, we evaluate the socio-economic cost of carbon emissions from seaborne trade activity per borne ton and per consumed ton fuel in both Business as Usual (BAU) and METS state. Then we continue to evaluate the relative socio-economic effect with regional segmentation, transportation mode, and the expected effect on the shipping industry from both the economic and environmental perspective.

The METS economic model is calibrated with the Fuel Consumption data (FC), forecasted FC growth rate (based on the proportion between FC growth rate and global trade growth rate), forecasted emission abatement rate (based on EU-ETS actual performance) and Emission Unit Allowance (EUA) prices. This generates an economic evaluation based on multiple $\mathrm{CO}_{2}$ emission scenarios, allowing us to estimate the socio-economic impact on the environment from seaborne trade activity per borne ton criteria and per consumed ton fuel criteria in BAU State and METS State.

The research shows that METS is effective, for an annual reduction rate of $7 \%$ or more, but its efficiency is dependent upon the low growth rate of fuel demand. International shipping, in a state of BAU, is expected to increase its economic environmental influence by $356 \%$ from 2007 to 2030, with the maximum increase of $\mathrm{CO}_{2}$ emissions estimated at $324 \%$. In contrast, implementation of METS is expected to decrease $\mathrm{CO}_{2}$ emissions between 54 and $93 \%$ with the maximum emission growth rate at $207 \%$, and the minimum emission growth rate at $110 \%$. In relation to the BAU state and the external costs per ton of fuel consumed under BAU is expected to grow by $16 \%$, although with the expected rise in fuel prices this rate could decrease to $5 \%$. We found that under METS regulation this rate would grow only by up to $10 \%$ and decrease up to $4 \%$. In addition, we found that calculations of external cost per transported ton are likely to create an imbalance between payments and actual contribution to the pollution problem.

To conclude, the current sea freight tariff system does not account for the external costs of $\mathrm{CO}_{2}$ emissions, and therefore we suggest that International Maritime Organization (IMO), must take charge, lead and coordinate an international program of emission trade, that could achieve effective reductions with minimum impact on business activity.
\end{abstract}




\section{Introduction}

According to United Nations Conference on Trade and Development (UNCTAD), shipping is responsible for more than $80 \%$ of world trade and the total industry contribution to the world economy is estimated at 1-3 \% of world Gross Domestic Product (GDP). The global population growth is expected to cause an increase in the GDP of many countries and substantially increase the demand for food, raw materials etc. This will lead to an increase in the global demand for seaborne transport and consequently will increase $\mathrm{CO}_{2}$ emissions (estimated at 200-300 \% increase for mid-range scenarios, by 2050).

Carbon dioxide $\left(\mathrm{CO}_{2}\right)$ is primary greenhouse gas (GHG) emitted by ships and has a global warming potential of $98 \%$. According to a study by the IMO, which is in charge with overseeing environmental preservation and the maintenance of ocean resources, maritime shipping is estimated to be responsible for $3.3 \%$ of the global $\mathrm{CO}_{2}$ emitted in 2007. This translates to 1050 million tons of $\mathrm{CO}_{2}$ annually (while international shipping is accountable for $2.7 \%$ ), a level of emissions equivalent to that of a developed country (e.g., Germany). A common means of reducing emission of $\mathrm{CO}_{2}$ is slowing down the general sailing speed, or "Slow Steaming", which reduces emission at sea in the short run but conversely is predicted to bring an increase in $\mathrm{CO}_{2}$ emission levels on land in the long run (Buhaug et al. 2009).

Due to its international nature, the shipping sector differs from other transportation sectors, which are subject to local laws more than other transportation modes. International maritime shipping requires a unique set of rules and standards in order to function properly and satisfy increasing demand.

As a result of increasing environmental awareness, IMO developed a mandatory technological tool and standards for new ships (Energy Efficiency Design Index - EEDI) and voluntary operational measures for ongoing shipping operators (Ship Energy Efficiency Management Plan - SEEMP and Energy Efficiency Operational Index - EEOI), in order to assist them with the GHG abatement efforts. IMO also identifies the operational and economic benefits of implementing their suggested tools.

The IMO lacks information concerning the scope of accompanying costs of reduction efforts, due to the great diversity in the field. This problem could be solved by the application of our trade system, defined as Marine Emission Trading Scheme (METS) for emission permits, which decreases both overall emissions and the costs of emissions reduction.

In this research, we evaluate the environmental economic impact of shipping from the perspective of $\mathrm{CO}_{2}$ emissions, by implementing METS that we defined; this trading scheme is based on the EU-ETS program with adjustments for the shipping industry needs.

First, we evaluate the socio-economic cost of carbon emission from the seaborne trade activity per borne ton criteria and per consumed ton of fuel criteria in BAU state (with no attempts at reduction) and METS state.

Then we continue to evaluate the relative cost of socio-economic effect with regional segmentation, transportation mode and the expected effect on the shipping industry from the economic and environmental perspective.

The METS economic model is calibrated with the FC data, forecasted FC growth rate (based on the proportion between FC growth rate and global trade growth rate), 
forecasted emission abatement rate (based on EU-ETS actual performance) and EUA prices. This generates an economic evaluation basing on multiple $\mathrm{CO}_{2}$ emission scenarios, allowing us to estimate the socio-economic impact on the environment from the seaborne trade activity per borne ton criteria and per consumed ton fuel criteria in BAU State and METS State.

This paper is structured as follows. Section 2 reviews the theoretical background and lays the foundation for the model. Section 3 explains key variables and assumptions used for the METS model. The results are presented in Section 4. Section 5 concludes with a discussion, summary and conclusions.

\section{Theoretical background}

The idea of trade in allocations permits was implied in the work of the economist Ronald Coase (1960, "Theory of Social Cost"), in which he claimed that if property rights were well-defined, then it would be possible to ensure efficient allocation of resources in spite of the existence of externalities (Coase 1960). This trade mechanism continued to be formed and evolve, and received its characteristics in the continuing work that was done by researchers (Crocker 1966; Dales 1968; Montgomery 1972), while a formal program for trade in emission permits was first introduced in 1974 by the US Environmental Protection Agency (EPA).

This program has allowed commercial companies, for the first time, to trade emission permits (allocations) between emission sources from within the organization as long as the total emission does not exceed its quota. (Foster and Hahn 1995; Hahn and Hester 1989; Tietenberg 1985; Freeman and Kolstad 2007). In 1997, significant progress was made when the trade program was declared open to trade between companies themselves.

In fact, since the 80's the emissions trading-mechanism act has served as a leading policy tool for the EPA in effort to reduce emissions (mostly sulfuric dioxide) and as a leading tool to cope with climate change phenomena. The rationale behind this tool lies in the fact that in terms of cost-benefit, this tool is more efficient and flexible than other existing alternatives (Goulder 2013).

On the other hand, this mechanism is not always more efficient than other alternatives, i.e., setting the price for a single emission unit and letting the market determine the amount emitted (emission levy). In fact, the best method for dealing with the reduction problem depends on the amount of uncertainty and the level of information available about the marginal abatement costs (Weitzman 1974). As a result, IMO has recognized that implementation of technological tools (EEDI) with operational performance indicators (SEEMP and EEOI) will not be sufficient or effective in the reduction of GHG in the shipping industry respective to the global trade growth forecast analysis, and these efforts are expected to erode and lose the effectiveness. With the understanding that these tools are not enough, IMO has decided to conjoin marketbased measures, together with technological and operational tools, in effort to reduce emissions effectively and economically efficiently (IMO 2009, Buhaug et al. 2009).

12 plan proposals for emissions reduction based on the market mechanism were presented and discussed at the following IMO conferences: GHG-WG 1/5/3; GHG-WG $1 /$ 5/5; GHG-WG 1/5/6; GHG-WG 1/5/7; MPEC 58/4/19 MPEC 58/4/25; MPEC 60/4/8; MPEC 60/4/37; MPEC 60/4/40; MPEC 60/4/12; MPEC 60/4/39; MPEC 60/4/22; MPEC 60/4/26; MPEC 60/4/41; MPEC 60/4/10 and MPEC 60/4/55. 
Two main types of market-based instruments have matured and now are under consideration by the MEPC:

- The International Compensation Fund (ICF)

- Marine Emission Trade Scheme (METS)

\section{International Compensation Fund - ICF}

The program is based on a tax levy that will be imposed on all types of fuel in the shipping industry (per ton). The money will be collected for the benefit of a support fund.

The fund's money will mainly finance projects, research, and development for means to reduce emissions in the shipping industry and improve the efficiency of the functioning of the global fleet.

The guiding principle relies on the idea that the tax levy takes into account the variance in the $\mathrm{CO}_{2}$ emitted from various fuel types. The levy can be paid through refineries, vessels, bunker stations, port authorities, or any other combination (further details of the payment mechanism can be found in GHG-WG 1/5/1 report). Moreover, establishment and operation of the ICF will require the establishment of an organization that will track the purchase of fuel and GHG emitted for every existing vessel.

One of the main disadvantages in the current program lies in the fact that this program leaves the polluter with the dilemma of either investing in efforts of reduction, or alternatively to continue BAU and pay the tax levy, thus creating high uncertainty in the reduction effort. The effectiveness of this mechanism for low tax is questionable. In addition, this mechanism holds a certain potential for the polluter to pass on the tax burden to the shipper (i.e., the consumer) therefore harming the consumer surplus from both sides; pollution and money resources, thus may carry on a potential threat to the global economy.

\section{Marine Emissions Trade Scheme - METS}

The METS is based on an emissions trading-mechanism and authority trade in emission permits between pollutants in the shipping industry. It has been presented and discussed in the following IMO conventions: GHG-WG 1/5/3; GHG-WG 1/5/5; GHGWG 1/5/6; GHG-WG 1/5/7; MEPC 58/4/19 \& MEPC 58/4/25; MPEC 60/4/8; MPEC 60/4/37; MPEC 60/4/40; MPEC 60/4/12; MPEC 60/4/39; MPEC 60/4/22; MPEC 60/4/ 26; MPEC 60/4/41; MPEC 60/4/10 and MPEC 60/4/55.

The final presentation of the program was done by the State of Norway (Buhaug et al. 2009, IMO 2010). This program differs from the previous plan (ICF) in financing and operation, which is done by auction of emission permits. This trading mechanism in this program is designed to function as a global mechanism, which would cover all emissions of all types of vessels above a certain size (to be determined later). The mechanism is designed to include an interim mechanism which will prevent or reduce as much as possible the damage to the marine/economic activities.

The mechanism will operate under the constraint of a global emissions quota (total) for the entire shipping industry, based on emission data from the past and according to target reduction principles and guidelines published by the Intergovernmental Panel on Climate Change (IPCC) organization (IPCC 2007). The inventory of additional 
emission permits will be set in the optimal manner, in order to bring an effective reduction while minimizing the potential threat to the global economy. The inventory of the permits will be updated periodically, similar to other trade programs.

The METS mechanism will also be "open" to other trading schemes in other programs (e.g., EU-ETS etc.) This will ensure reduction in amount of global emissions, and on the other hand have the potential of minimizing the abatement cost, thereby mitigating the expected increase in freight rates and minimizing transport costs.

Due to the potential of the phenomenon of "carbon leakage" (UNFCCC 2009), the legal entity that will be monitored and will be responsible for the amount of emissions in this program will be defined as a single vessel, regardless of the country in which it is registered or the flag it sails (e.g., "flag of convenience"). Moreover, the legal entity that will coordinate and actually execute the purchase process and, in the future, the trade in surplus emission permits will be defined as the vessel operator. The allocation mechanism of the emission permits in the shipping industry will be executed according to one of the following ways: (a) auction, (b) allocation based on past activity indices "grandfather allowance" (based on seaborne tons), (c) allocation according to regional activity, (d) a combination of the above. Any of the above options will be evaluated in terms of impact, financial return and efficiency.

A brief explanation of assumptions regarding the demand and supply mechanism for international sea freight activity with the implementation and integration of trade mechanism (METS) in maritime shipping is presented Ben-Hakoun et al. (2015), Section 2.2. For more basic review see environmental economic book (Tietenberg 2006).

\section{Methodology}

The economic approach in this study is based on ETS methodology, providing practical economic values rather than hypothetical values.

Using excel spreadsheet functionality, we have built a financial appraisal model used in this analysis.

By using actual prices of EUA, we have been able to assess the external effects of the carbon emission in the shipping industry (BAU and METS state). This allows us to more comprehensively understand the abatement potential inherent in the use of the METS mechanism.

We assume that the price of permits used in this model reflect a global carbon market equilibrium.

\section{Model description and input data}

The model applies to two possible situations, the first, BAU, with no reduction efforts and the second with the fully implemented METS program. The model is designed for two periods; the base year 2007 and target year 2030.

For the BAU situation, we assume that there are no reduction efforts based on emission trading programs. This assumption applies for the model years 2007-2030.

For the METS situation, there are two time frames. The short run period, from 2007 until 2024, which relates to constant reduction efforts that will be specified further in this article. The long run period, from 2025 to 2030, is a period of many changes in the global shipping fleet characterized by significant technological improvements that will 
exert considerable influence on the amount of carbon emissions in the entire shipping industry, and international shipping in particular. This time frame was used due to the fact that "life expectancy" of a single vessel is between 25 and 35 years, therefore, in order to obtain the most applicable results in relation to actual ship use, our model will be limited to two periods of activity (Buhaug et al. 2009).

For this reason, we have defined three main scenarios of FC growth rates (Low, Best and High) that branch out to a wide range of EUA prices possibilities (a total of nine) and three "Black" scenarios, which will be used as a means of characterization and parameters of this economic assessment study. These 12 scenarios provide us with a bounded economic estimation (Appendix 1: Tables 3 and 4).

The Low Bound scenario: reflects the minimal growth of FC in the global shipping industry/international shipping; assuming that the demand for the sea freight services continues to increase due to natural population growth and a minimal increase in purchasing power. As a result of a decrease in productivity in the western world and a minimal increase in the middle class economic status (mostly due to low economic growth in middle-class welfare in countries such as India, China, Malaysia, etc.).

The Best bound scenario: reflects the natural growth of FC, mostly based on the growth prediction of International Monetary Fund (IMF), natural population growth, and a natural increase in the purchasing power, as a result of a natural increase in productivity, and a natural increase in the middle class economic status worldwide (mostly due to natural economic growth in countries such as: India, China, Malaysia, etc.).

The High bound scenario: reflects a maximum growth of FC, based on the growth data presented in the early 2000's, representing years with high FC growth rate and increase in demand for sea freight transportation service.

For each scenario, we assume three options for emission abatement, varying in size of reduction of carbon emissions at a global level but without a regional specificity. Each scenario reflects different levels of EUA prices consistent with the required level of abatement according to our METS (e.g., - for low rate of abatement, we assumed that the price of EUA is low, as a result of high surplus in EUA and low demand, and similarly, same can be assumed for Best and High).

Inspired by the "Fisher effect" (Fisher 1930), we choose FC growth rates $\alpha_{t}^{i, s}$ (in period $\mathrm{t}$, area i and growth rates $s \in\{$ High, Best, Low $\}$ ), and reduction rates $\beta_{t}^{s}$ small enough that their multiplication would give us a negligible number, which allow us to use the "Fisher effect" in our model as a sum of the rates $\theta_{t}^{i, s}$ in the approximation equation, as justified in the following eq. 1 .

$$
\begin{aligned}
& \alpha_{t}^{i, s}<<\beta_{t}^{s}<<1 \\
& \left(1+\theta_{t}^{i, s}\right)=\left(1+\alpha_{t}^{i, s}\right)\left(1-\beta_{t}^{s}\right)=1+\alpha_{t}^{i, s}-\beta_{t}^{s}-\quad \alpha_{t}^{i, s} \cdot \beta_{t}^{s} \\
& \forall \alpha_{t}^{i, s}<<<\beta_{t}^{s}<<1 \rightarrow \alpha_{t}^{l, s} \cdot \beta_{t}^{s} \cong 0 \\
& \theta_{t}^{i, s}=\alpha_{t}^{i, s}-\beta_{t}^{s}-\alpha_{t}^{i, s} \cdot \beta_{t}^{s} \cong \alpha_{t}^{i, s}-\beta_{t}^{s} \\
& \left(1+\theta_{t}^{i, s}\right)=\left(1+\alpha_{t}^{i, s}\right)\left(1-\beta_{t}^{s}\right) \cong 1+\alpha_{t}^{i, s}-\beta_{t}^{s}
\end{aligned}
$$


The Black scenario: reflects three different growth scenarios of FC (low, medium and high), all of which share a similar emission abatement level (minimal) and the highest cost of EUA for these scenarios.

The summary table for international shipping and for global shipping scenarios can be found at the end of this paper under Appendix 1.

It is important to note that the model does not relate to legal issues concerning enforcement and application of the model in the industry, or international shipping in particular. It is assumed that these issues were resolved and do not relate to the number of emission permits that exist in the model. Further, we assume that the existing number of emission permits in the METS market is optimal according to the maritime environmental economic policy, in light of social and economic growth.

\section{Fuel consumption data}

The METS economic model is adjusted with the $\mathrm{FC}$ data $\left(\mathrm{Mt}^{1}\right)$, as they were presented in the IMO research, this data will be used as a basis of this study.

The reference year for the model calculations is 2007, in which the FC rate for the global shipping industry is estimated at the level of 333Mt and for international shipping at the level of 277Mt. This data was estimated top down (from general to specific).

In 2007 the FC data was gathered in the most detailed and comprehensive way compared to past years due to the use of the data from automatic identification system and IMO reports.

\section{Carbon factor data}

Heavy Fuel Oil or Residual Fuel Oil (HFO/RFO) mixture (level 6) is the most common fuel in the industry today (77 \% of the total annual FC). Our model will assumed a carbon factor of 3.13 (Kg leaked carbon/ton fuel oil), which IMO researchers used to calculate the level of carbon emissions for every type of engine (marine engine, auxiliary engine) based on the IPCC (2007) scenarios.

Multiplying the FC data with the carbon constant will generate the potential total amount of carbon emitted in the shipping industry.

\section{Emission data by segmentation of means of transport}

We will start with understanding the mixture and composition of the carbon emissions, by using the results of the research (Eide 2009), which details in its findings the relative contribution of emissions caused by means of sea freight transportation in the international shipping. In addition, we will use the results of administrative work of IMO MEPC 60/WP.5 conference, which details in its findings the relative contribution of emissions caused by means of sea freight transportation in the global shipping industry.

From there we will segment sea freight transportation in the global shipping industry and in international shipping as follows: dry bulk, liquid bulk, container cargo, general cargo (neo bulk), which will be referred to from now on in tables and charts as D. Bulk (Dry), L. Bulk (Liquid), Container and Neo Bulk (summary table can be found under Appendices 2 \& 3). 
These means of transport are a general name for the four main groups of sea freight transportation; they are different from one another by the level of required energy, vessel size, geographic activity area, etc.

\section{Borne ton data by geographic activity}

In order to understand the relations between segmentation of sea freight transportation and geographic activity area, we will use the borne tone data (Mt) from the years 1997-2007, based on the IHS-GI analytics data.

This data is segmented by means of seaborne transport (import and export) and interactions between the following geographic activity areas: Middle East, Europe, America, Asia (Far East), Asia ISC (Indian sub-continent), Asia Arab and Africa, according to the policy segmentation of Lloyd's Marine Intelligence Unit (LMIU). This allows us to receive annual data such as: total borne ton in each area (Mt), a segmentation of the total ton transported by means of sea freight transportation in each area $(\mathrm{Mt})$ and interactions between areas by the borne ton $(\mathrm{Mt})$ along with segmentation by means of sea freight transportation (Mt). Due to the fact that the nominal data for borne ton at this moment is not relevant, we will continue to process the data by percentage. Using the total seaborne tons in a given year will serve as a reference for an annual allocation. We will perform the segmentation of the seaborne tons by means of sea freight transportation (\%), interactions between areas (\%) by sea borne tons. The results of this action will grant us ten tables (one for each year - 1997-2007) of sea borne ton relations (\%), segments by area (\%), means of sea freight transportation (\%) and interactions between areas (\%).

We will then use these tables to calculate the average for each resulting in a weight table (with a standard deviation of $2 \%$ ) that will reflect the existing relation between means of sea freight transportation and its interactions between areas by the sea borne tons, which we will use in our further calculations.

Due to the fact, data in our possession is valid only for international shipping; we will not perform similar analysis according to geographic activity segmentation for the shipping industry, (summary table for international shipping can be found under Appendix 4).

In addition, it is important to note that FC data in this study is based on IMO estimation of consumption at a global level and does not reflect FC by geographical area of activity. In order to receive FC data by segments of area activity, we will use the emission segmentation findings from Eide and MEPC 60/WP 2010 study. Therefore, by multiplying the total amount of emissions with weight table (sea borne tons), will result in a rough estimate of the amount of emissions for a specific area in relation to the means of transport, under a simplified assumption justified in the eq. 2 below.

Explanation: Assume that $Y^{j}$ is the total amount of carbon emissions caused by sea freight transportation mode $j$. Therefore, multiplying it with the ratio $\frac{X_{i}^{Y}}{\sum X_{i}^{Y}}$, where $X_{i}^{Y}$ is the sea borne ton by means of sea freight transportation $j$ in area $i$, and $\sum X_{i}^{Y}$ is the total amount of borne ton, will give us to a rough estimation of the amount of carbon emission caused by means of sea freight transportation $j$ in the area $i$, that is $Y_{i}^{j}$.

$$
Y_{i}^{j} \approx \frac{X_{i}^{Y}}{\sum X_{i}^{Y}} \cdot Y^{j}
$$


Roughly estimation in size of carbon emissions by means of sea freight transportation $j$ in area $i$.

\section{EUA prices}

The cost for a single emission permit can be considered a marginal cost for a single ton of carbon emission abatement. We will use the benefit transfer approach and rely on EU-ETS market performances for pollution permits and sales forecasts, the model will include three EUA price scenarios that will allow us a range of costs for the High Bound and Low Bound (Appendix 1: Table 1).

The EU-ETS mechanism suffers from a high level of uncertainty due to being subject to a large number of opinions and interested parties (states, lawmakers, lobbyists, etc.).

Therefore, we can assume that until 2020, no meaningful change is expected in EUA costs, so the coefficient discount rate $\left(r_{t}\right.$ - discount rate) in these years will be zero. For the years 2020-2030, we assume a coefficient growth in EUA costs at a rate of $10 \%$ (decade growth ratio compared to the previous year), which represents a moderate increase in available resources.

Bounds for the cost of emission permits in the METS mechanism will be based on the average of EUA prices, taken from relatively stable period of the EU-ETS mechanism, which in our analysis has the potential to reflect a global price for carbon emissions.

\section{Growth rate data for FC}

For FC growth estimations in the global shipping industry, we will rely on findings from UNCTAD report, which found a high correlation between growth of industrial activity, growth of world GDP and the demand for sea freight transportation, without relation to trading growth between areas (UNCTAD, 2011). These findings are supported by other research in the field, allowing us to perform a rough estimate of the area's growth rate in FC means (Eyring et al., 2007; Corbett, Firestone and Wang, 2007; Corbett et al. 2007; EnSys Energy \& Systems Inc. and Navigistics Consulting, 2007).

However, these finding are predicted to lose the effectiveness in the next decades due to development and transition of the world market, from activity based on industry and goods to activity based on services and knowledge (according to IPCC-B1 scenario, 1992).

Therefore, for the shipping industry, we assume a unified growth rate in all areas for FC, in which low growth rate are based on "EnSys" research findings. Best growth rates are based on the world GDP growth rate (according to IMF forecasts between 2012 and 2018, which reflect a more consistent increase in the world GDP for the next half decade) and high growth rates based on the world GDP growth rate between 1981 and 2007, which can be described as one of the periods with the highest economic growth.

For FC growth estimation of the international shipping, we use findings from the IMF data, in order to receive realistic growth data by area (in annual growth rate, \%), for developing countries we use nominal GDP data, for developed countries we use the nominal Purchasing Power Parity (PPP) data (Europe and America).

Using a simplified assumption that the area growth rate of FC is relatively close to the size of the GDP growth rate, will result in a matrix of the growth rates of FC by area. In order to minimize external impacts, we assume a technological fixation in the 
industry (based on the existing technology in the industry in 2007) and assume that the number of new vessels joining the world fleet is equal in size of energy consumption to those that were deducted from the global fleet. This assumes that the number of vessels which were deducted is in average size of $3 \%$ and the amount of the new vessels joining the world fleet is in average size of $2.1 \%$, excluding container vessels which are estimated at $5.2 \%$ (Buhaug et al. 2009; (IMO MEPC 63/INF.2, 2011; Bazari and Longva, 2011).

Based on data of Clarkson Research Services Limited Company (CRSL), we assume that the growth rate per borne ton is $3.7 \%$ per year, which is a unified growth rate for all means of sea freight transportation. We believe that the chosen growth rate will represents the FC growth best for sea freight activity in the international and global shipping sector in the following decades.

Furthermore, we assume that until year 2025 there are no expected meaningful increases in fuel prices or decreases in the level of carbon emissions, due to the life expectancy of a single vessel in the current world fleet (i.e., the current fleet continues to be used, and only after 2025, innovative technologies will be used). After 2025, we assume that the number of new vessels using innovative propulsion technologies (e.g., - Liquefied Natural Gas LNG or Bio LNG as a fuel of choice for vessels), advance achieved in vessel design and efficiency, fleet age and advanced air filtration systems will have come to a critic mass and considerably influence the amount of worldwide carbon emissions. This will result in a drastic reduction in the total level of carbon emission in the shipping industry.

\section{Reduction rate data according to scenarios}

Recent research that reviewed the effectiveness of the EU-ETS program in reduction of carbon levels discovered that the EU-ETS program can be accounted for estimated reduction rate between 2 and $4 \%$ of the total capped emissions (Laing et al. 2013), with optimistic estimates that the reduction rate can reach $7 \%$ of the total capped emissions (Branger et al. 2013).

According to IMO research, by combining the technological and operational tools, it is possible to reach reduction rate level of 10 to $50 \%$ or more. From analyzing the FC growth prediction for the shipping industry, these results are predicted to erode and lose effectiveness.

Another research performed by IMO, found that the reduction rate for 2020 can be estimated at 9-16\% (compared to 2007), and for the years 2020-2030, estimated at 17-25\% compared to the BAU situation (with only the implementation of voluntary tools - EEDI, etc.) (IMO MEPC 62, 2011). Therefore, we can assume that until 2015 (reference year for METS model implementation), there is no meaningful reduction effort, so all the scenarios in this period will adjust with a reduction rate of $0 \%$.

Summary table for reduction rate (of the total capped emission, per year) and other model inputs for the international maritime shipping and the global shipping (Appendix 1: Tables 3 and 4).

Implementation of innovative propulsion technologies, based on Liquefied Biogas (LBG), has the potential to reduce emission for more than $80 \%$. However, a life-cycle assessment study found that the effect on climate change is expected to be at the same level of impact as with using HFO as a fuel of choice. Therefore LBG fuel as a fuel of choice for vessels operators was not included in this paper (see Brynolf et al. 2014). 


\section{Level of accuracy and reliability of results}

The volatility in EUA costs plays a main role in the model, as it functions as a bound that enables us to receive an economic estimate for the pollution problem caused by the shipping industry.

In addition, the uncertainty in the FC data, as it was defined by IMO, is in the deflection range of $20 \%$ (high and low bound). Along with the continuation of erosion correlation between the growth rate of GDP and the demand for sea freight transportation, have the potential to reduce the reliability of the model's results. On the other hand, the model uses a relatively small carbon emission factor, which can significantly increase the estimation of high social costs and harm the effectiveness of the model. Therefore, based on the existing data we can say that the model is sufficient to provide an economic estimation for the impact of the international shipping industry on the environment from the aspect of carbon emissions.

Result analysis reveals a spectrum of scenarios for international shipping: High-LowHigh, High-Low-Low, Best-Low-High, Best-Low-Low and Low-High-High. There is a high correlation, which allows us to conduct a proper estimation on the impact of implementing METS model in these various scenarios. Meanwhile, the reliability and validity of the model stands at $66 \%$ for the Best and High growth scenarios and at $44 \%$ for the Low scenario, while the rest of the scenarios not mentioned above benefit from a relatively high level of reliability (77-94\%), though are unreliable due to a low correlation level (Appendix 1: Table 2).

For global shipping, results indicate that for the following scenarios: High-LowHigh, High-Low-Low, Best-Low-High, Best-Low-Low and Low-High-High, there is a high correlation allowing for proper estimation of the impact of implementing the METS model in these scenarios. The reliability and validity of the model stands at $64-68 \%$ for the Best and High growth scenarios and at $98 \%$ for the Low scenario, while the remaining scenarios not mentioned above benefit from a relatively high level of reliability (79-96\%), though are unreliable due to a low correlation level (Appendix 1: Table 2).

\section{Model results}

\section{Socio-economic effect, global (domestic and international) and international shipping - FC aspect}

In examining the economic effect of carbon emissions (BAU Vs. METS state) in relation to environmental economic cost per ton fuel consumed, we assumed that the fuel component was an important element of sea freight rates and maritime transport costs. Therefore, we addressed the selected periods: 2007, 2015, 2020, 2025, and 2030, which serve as indicators for the effectiveness and reduction potential of the METS mechanism, (summary table for result in the international shipping can be found under Appendix 5: Tables 8 to 11).

Findings from the model for international shipping in BAU state shows:

For Low bound scenarios, the socio-economic cost for one ton of consumed fuel is estimated at a rate of $\$ 20.72-\$ 22.29$ per ton of consumed fuel (for 2007, 2030 respectively). For Best bound scenarios, the socio-economic cost for one ton of consumed fuel is estimated at a rate of $\$ 42.63-\$ 46.89$ per ton of consumed fuel (for 2007,2030 respectively). 
For High bound scenarios, the socio-economic cost for one ton of consumed fuel is estimated at a rate of $\$ 72.46-\$ 79.81$ per ton of consumed fuel (for 2007, 2030 respectively). Black scenarios, in the BAU state are equivalent to the high cost in each of the previous scenarios, and therefore are not currently reflected.

For global shipping in the BAU state, findings are similar to the results received for international shipping. This is due to the fact that the effect of carbon emission per ton of consumed fuel has the same economic effect in accordance with the scenarios (Fig. 1).

These costs are relatively high, compared to the fuel prices in the shipping industry.

As findings indicate, the economic effect of carbon emissions gradually grew throughout the years, which can be explained as a result of expected growth in trade leading to growth in FC and as a result of an expected increase in EUA costs, which its inventory are reduced on periodic basis.

When we examine the economic environmental effect from the implementation of the METS mechanism in the international shipping, findings from the model can be characterized by a decrease in the average socio-economic impact per ton of consumed fuel both from the shipping industry and international shipping, in relation to the BAU state (Figs. 2 and 3).

Year 2015 - This is the first year in which the METS mechanism was implemented. The average cost of reduction efforts in relation to a ton of consumed fuel was estimated at a rate of $\$ 0.39-\$ 6.97$ in relation to the implemented reduction rate (i.e., - a high cost for a high reduction rate and a medium cost for a medium reduction rate, etc.).

FC rate grows between 135 and $168 \%$ in relation to the reference year according to the growth scenarios. The potential reduction level is between 2 and $9 \%$ annually, in relation to the reduction rate. As expected, the METS mechanism is not effective in reducing the level of carbon emissions below the reference year.

Year 2020 - The average cost of reduction efforts in relation to a ton of consumed fuel are estimated between $\$ 2.44$ and $\$ 36.25$ in relation to the implemented reduction rate.

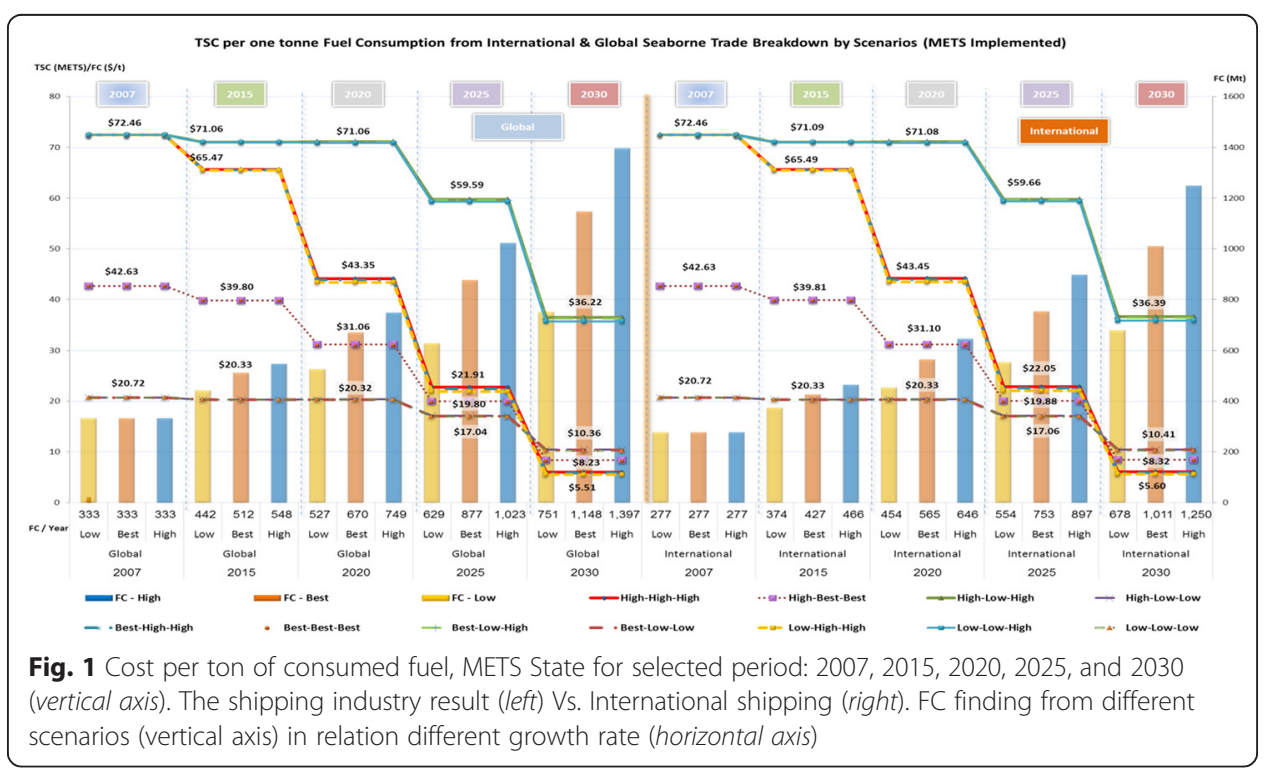




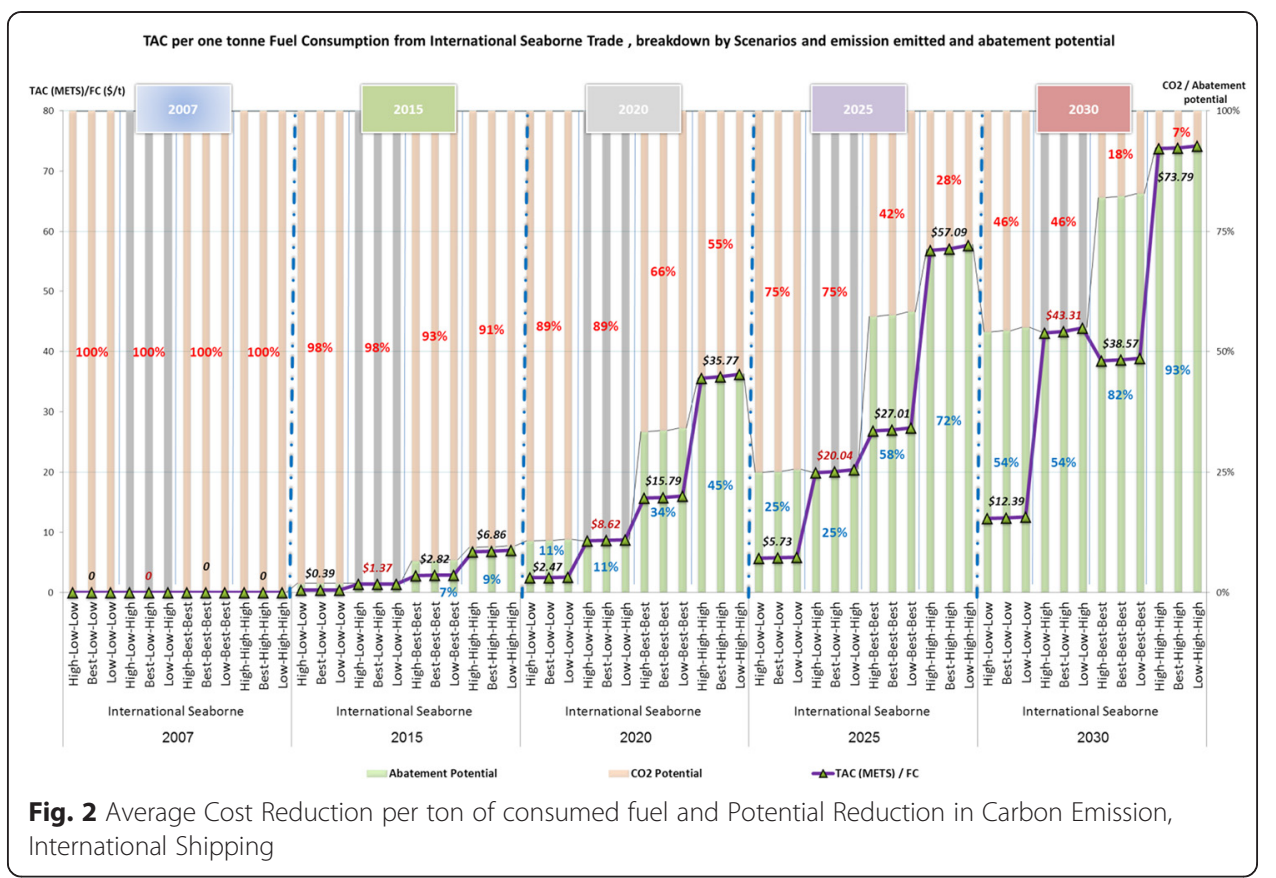

FC rate grows between 164 and $233 \%$ in relation to the reference year according to the growth scenarios. The potential reduction level is between 11 and $45 \%$ in relation to the reduction rate. The METS mechanism is effective only for the Low-High-High scenario, which is characterized by low growth rates and a reduction rate above $10 \%$.

At a greater than $45 \%$ reduction level, this period is characterized by an increase in reduction costs. These increases are a result of high reduction efforts that required massive resources and investment, which may lead to high costs per one ton of fuel consumed.

Year 2025 - This is a period of numerous changes in the global shipping fleet characterized by significant technological improvements (e.g., - new propulsion technologies, etc.) that will exert considerable influence on the amount of carbon emissions in the entire shipping industry, and international shipping in particular.

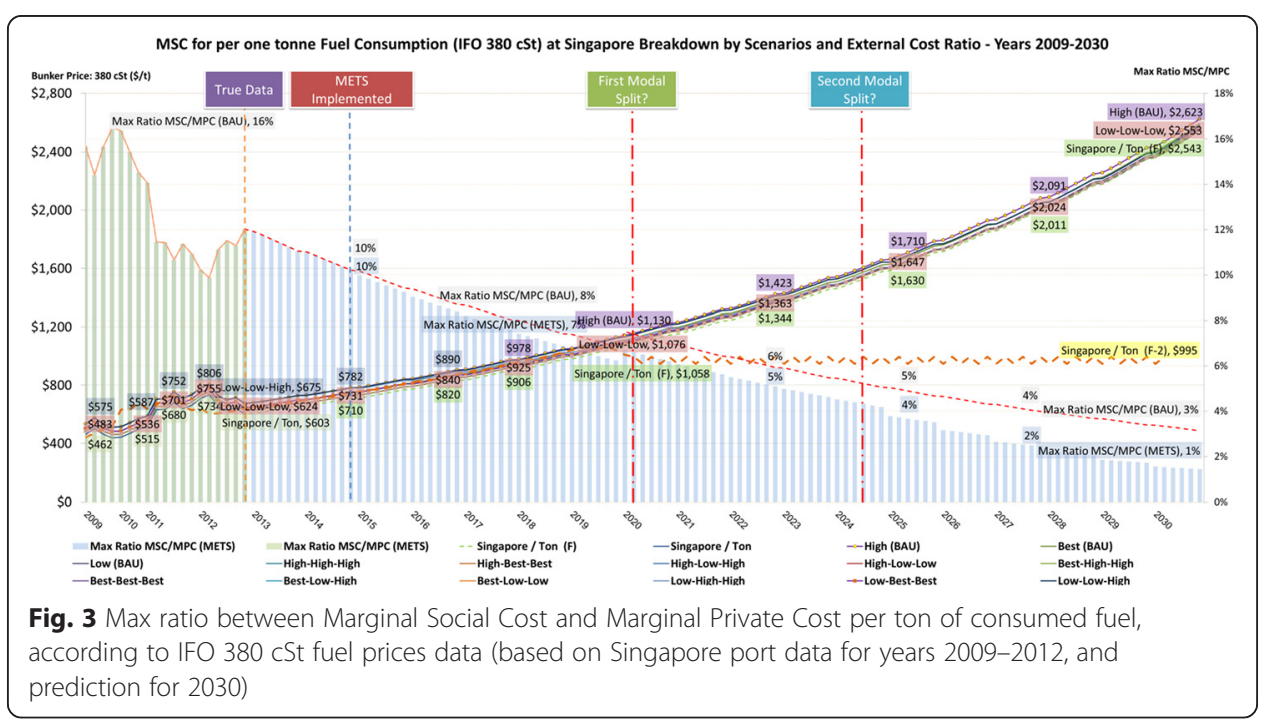


Average costs per ton of fuel are estimated between $\$ 5.82$ and $\$ 57.65$ in relation to the implemented reduction rates and scenarios. FC rate grows between 200 and $324 \%$ in relation to the reference year according to the growth scenarios. The potential reduction level is between 25 and $72 \%$ in relation to the reduction rate. The METS mechanism is effective in reducing the level of emissions below the reference year (e.g., 2007) for the scenarios that are characterized with the reduction rate higher than $7 \%$, regardless of growth rates.

Year 2030 - This is five years after the expected changes in the global shipping fleet have occurred.

Average costs per ton of fuel are estimated between $\$ 12.55$ and $\$ 74.11$ in relation to the implemented reduction rates. FC rate grows between 245 and $451 \%$ in relation to the reference year according to the growth scenarios. The potential reduction level is between 54 and $93 \%$ in relation to the reduction rate. The METS mechanism is effective in reducing the level of emissions below the reference year (e.g., 2007) for the scenarios that are characterized with the reduction rate higher than $7 \%$, regardless of the growth rates.

Black Scenarios - For the years 2015-2024, the average cost per ton of consumed fuel converges to $\$ 8.62$, a sharp reduction in relation to BAU state, mainly due to high cost of EUA for these scenarios. In the year 2030, after an increase in reduction rate (up from 2 to $10 \%$ ), costs are estimated at an average of $\$ 43$ per ton of fuel consumed. The potential for reduction in relation to the cost has been eroded.

From this finding, we see that in the year 2020 the potential for reduction stands at a rate of $11 \%$. After five years, it increases to $25 \%$ and in year 2030 it converges to $54 \%$. The slow erosion process tells us that the effectiveness and efficiency of the mechanism have occurred as a result of high costs per one ton of fuel consumed. As expected, the METS mechanism is not effective in reducing the level of carbon emissions below the reference year.

As for the global shipping (METS state), findings are similar (differs in cents) to the results that were received for international shipping. This is due to the fact that the effect of carbon emission per ton of consumed fuel has the same economic effect in accordance to the scenarios.

\section{Socio-Economic Impact, International Shipping - Segmentation According to Regions and Means of Transport}

International sea freight contributes differently in terms of its socio-economic impact on the environment both on a regional level and as means of transport. This difference is due to fact that trade is often not balanced; some countries mainly export, while others mainly import. This phenomenon has led to a varying contribution of carbon emissions that differs at the regional level and at the level of the means of transport, but has the same environmental impact regardless of the source and location of emissions.

Today, international freight is mostly conducted by means of sea transportation, which is not homogenous in frequency, quantity per region, or means of transport used.

Due to the lack of information available in the data for seaborne ton, this topic will deal only with the socio-economic assessment of carbon emitted from international 
shipping and segmentation according to regions and means of transport, based on data provided by the company IHS-GI in accordance with the policy segmentation of LMIU.

The core aim of this topic is to evaluate the effect of the METS mechanism on international shipping at the regional level, together with the socio-economic impact according to segmentation of means of transportation. Thus, it serves as a potential reference for decision-makers to target reduction activities and encourage reduction at both the regional level and on the level of means of transport.

An examination indicates that the most influential areas in terms of carbon emissions are: Asia - Far East (China, Japan, Malaysia, etc.), America (mainly North America) and Europe, regions with socio-economic influence so great that compared to them, other areas (Middle East, Africa, Asia Arab - countries of the Persian Gulf and similar) are negligible in terms of emissions and in terms of trade volume.

The data shows that the most influential socio-economic trading today is carried out in Asia - Far East.

Under the model assumptions for a BAU state without abatement effort, it appears that we predict an increase in the social cost from Asia - Far East region, while at the same time we expect a decrease in the social cost of the western area (mainly North America and Europe), a fact that is in line with the model assumptions regarding economic growth forecasts in the east as a result of an expected increase in welfare of the middle class and in labor productivity in developing countries.

In this section we chose to refer separately to the sub-continent of India, due to forecasts of rapid growth and weight ascribed to it in the economic literature, but nevertheless finding of this study indicate that over the years the sub-continent of India have a great potential to uphold its socio-economic influence, which stems from the fact that the sub-continent self-consumes and mostly feeds from independent sources.

Therefore, when we examine the economic impact caused by carbon emissions relative to the economic environmental cost according to segmentation by means of transportation and geographic area of activity, we do this under the assumption that a better understanding of the socio-economic impact according to regional segmentation and means of delivery of carbon emissions has a great potential to assist the decision makers with information that can be used to focus the reduction effort activity or the emissions reduction policy, thus avoid possible adverse effects in the economic development of the developing countries.

We are interested in paying the true cost of sea freight, nevertheless we acknowledge the fact that areas characterized by weak economic level often have low trade volumes and are expected to bear the external costs exactly like the areas characterized by stable or prosperous economic level, which are characterized by extensive trade that may suggest a greater economic environmental impact. Therefore, their contributions and influence on the external costs are perceived as higher.

We choose to address the following selected periods as a reference: 2007, 2010, 2015, 2020, 2025, and 2030, which will serve us as indicators for the effectiveness and potential reduction of the METS mechanism.

Due to the large number of scenarios, this study will address only the scenario HighLow-Low, Which has a higher logarithmic correlation coefficient $\left(R^{2}\right)$ for influential areas in terms of carbon emissions both under BAU and METS state (summary table 
for result in the international shipping can be found under Appendices 2, 3 \& 4: Tables 5,6 and 7 respectively).

High-Low-Low Scenario, in the BAU state finding shows:

- General cargo vessels (Neo Bulk), may account for $28 \%$ of the total social cost caused by international shipping in respect to carbon emissions, estimated in 2010 at 1.9 billion dollars, while Asia-F.East and the Americas are the influential socio-economic areas with valuation of $\$ 795$ and $\$ 507$ million, respectively (which together comprise a total of $66 \%$ of the total social cost of shipping means of general cargo vessels that year). As the years progress, the socio-economic impact of this shipping method grows however, the relations contribution ratio and growth rate are kept as a result of the low growth rate of seaborne tonnage of this means. As a result, in 2030, this means of transportation may still account for $28 \%$ of the total social cost, estimated at a potential total of 7.9 billion dollars, when in the socio-economically influential areas of East Asia, America, and Europe, a potential total will be $81 \%$ of the total social cost this year.

The socio-economic assessment for East Asia alone in 2030 is estimated at a potential total of 3.3 billion dollars, 1.7 times the influence of this area, while the regional socio-economic impact of America and Europe is estimated at a total of 2 and 1.1 billion dollars, respectively.

The carbon emission from general cargo vessels (neo bulk) are estimated to be 560Mt for the year 2025, and 1093 for the year 2030, an increase of 231 and $450 \%$ respectively; relatively to the reference year 2007.

- Container Shipping, characterized by particularly high growth rates, makes this means of sea freight transportation a significant polluter in terms of its socioeconomic impact.

It potentially accounts for $26.7 \%$ of the total social cost caused by international shipping in respect to carbon emissions, with a high potential to inherit the title of the means of sea freight transportation with the largest socio-economic impact, while swipe away relative parts from dry bulk and general cargo vessels (down from 16.4 to $15.8 \%$ for dry bulk and down from 23.4 to $22.7 \%$ for general cargo vessels of the total social cost in respect to carbon emissions). In 2010, the potential total social cost was estimated at the amount of 1.86 billion dollars, while Asia-F.East and America are the influential socio-economic areas with valuation of $\$ 759$ and $\$ 484$ million, respectively (which together comprise a potential total of $66 \%$ of the total social cost of shipping means of container vessels that year).

In 2030, this means of transportation is expected to grow by $400 \%$ in its potential influence of the total social cost (in reference to 2010), with an estimated amount of 7.62 billion dollars, when in influential socio-economic areas that are East Asia, America, and Europe with a potential total of $80 \%$ of the total social cost at this year.

The socio-economic assessment for East Asia alone is estimated at a total potential of 3.14 billion dollars, 4.1 times the influence of this area in 2010, while the regional socio-economic impact of the America and Europe estimated at a total potential of 1.9 and 1.1 billion dollars, respectively. 
The carbon emission from container shipping is estimated to be 535Mt for the year 2025, and 1043 for the year 2030, an increase of 231 and $450 \%$ respectively; relatively to the reference year 2007.

- Liquid bulk/tanker vessels used primarily in transporting fuels materials, chemicals etc., enjoying relatively high demand mainly from areas such as America and AsiaF.East, result of the increasing demand for energy in these areas. The reason for the latter is the ongoing increase in the EU efforts toward the reliance on renewable energy sources in current and previous decades caused to a decrease in Europe's demand for liquid bulk vessels.

The socio-economic impact of this shipping method is estimated in 2010 at the potential amount of 1.78 billion dollars and in 2030 at the potential amount of 7.3 billion dollars, a potential increase of $400 \%$. The influential socio-economic areas are America and Asia-F.East, which has been increasing gradually from 2010, from a socioeconomic valuation potential of $\$ 507$ and $\$ 795$ million (constituting together $66 \%$ of the total social cost of liquid bulk/tanker vessels this year) up to a total potential of 3.6 and 5.4 billion dollars in 2030, respectively.

The carbon emission potential from liquid bulk/tanker vessels are estimated to be $513 \mathrm{Mt}$ for the year 2020, and 1000 for the year 2030, an increase of 231 and $450 \%$ respectively; relatively to the reference year 2007.

- Dry bulk vessels are characterized by demand mainly originating from areas such as:

East Asia, Asia Arab, the Middle East and Europe.

The socio-economic impact of this shipping method estimated in 2010, at the potential amount of 1.36 billion dollars and in 2030, at the potential amount of 5.57 billion dollars, a potential increase of $400 \%$. The influential socio-economic areas are America and Asia-East, with valuation potential of $\$ 555$ and $\$ 354$ million respectively, and up to a total potential of 2.3 and 1.4 billion dollars in 2030, respectively. The carbon emission potential from dry bulk vessels are estimated to be 390Mt for the year 2020, and 763 for the year 2030, an increase of 231 and $450 \%$ respectively; relatively to the reference year 2007.

High-Low-Low Scenario, in the METS state findings shows:

In this scenario the METS mechanism, under the assumption from the year 2015, we observe an annual reduction rate of $2 \%$ until the year 2025 and an annual reduction rate of $10 \%$ for subsequent years (in absolute terms regardless to the regional contribution or contribution from different means of sea freight transportation).

In this section, we choose to address the selected periods as reference: 2020, 2025, and 2030, which will serve us as indicators for the effectiveness and potential reduction of METS mechanism, because finding from periods of 2010 and 2015 are similar to the BAU state.

- For General cargo vessels (Neo Bulk), the potential amount of social cost caused by international shipping in 2020 and in 2025 is estimated at a total of 3.15 and 3.9 billion 
dollars, respectively. Potential decrease is estimated between 15 and $25 \%$ of the amount of damage relative to the BAU state. Asia-F.East, America and Europe are the influential areas in terms of social damage with a potential valuation.

In 2030, the potential total social cost estimated at the amount of 3.3 billion dollars, a potential decrease of almost $54 \%$ of the amount of damage relative to the BAU state.

The reduction potential general cargo vessels are estimated to be $84 \mathrm{Mt}$ for the year 2020, and 591 for the year 2030 a potential decrease estimated between 15 and $54 \%$ of the amount of emitted carbon relative to the years in BAU scenario. The reason for the latter is that according to the model assumptions, from the year 2025, we may observe a period of numerous changes in the global shipping fleet characterized by significant technological improvements in a way that applying the METS mechanism combining with the new technologies implemented in the global shipping fleet, supposed to bring a potential decrease in the amount of carbon emission.

- Container Shipping, characterized by particularly high growth rates, which make this means of sea freight transportation a significant polluter in terms of its socio-economic impact.

In 2010, the potential socio-economic impact of this shipping method estimated in amount of 1.86 billion dollars for the BAU state. After the implementation of the METS mechanism the potential amount in 2020 and in 2025 is estimated at a total of 3.01 and 3.72 billion dollars, while Asia F.East and the America are the most impactful areas in terms of social damage with a valuation of 1.32 and 0.78 billion dollars for 2020 respectively, and valuation of 1.7 and 0.87 billion dollars in 2025, respectively. Potential decrease of 15-17\% compared to the amount of potential damage in the prior state, BAU, in which we have seen an increase in the estimated rate of potential damage $38-39 \%$.

In 2030, the potential socio-economic impact of this shipping method estimated at the amount of 3.1 billion dollars. The reduction potential from container shipping is estimated to be $80 \mathrm{Mt}$ for the year 2020, and 564 for the year 2030 a potential decrease estimated between 15 and $54 \%$ of the amount of emitted carbon relative to the years in BAU state.

- For the Liquid bulk/tanker vessels, the potential socio-economic impact of this shipping method estimated in 2020, at the amount of 2.88 billion dollars and in 2030, at the amount of 3 billion dollars.

The influential socio-economic areas are America and Asia-F.East, with a valuation of 0.75 and 1.27 billion dollars for 2020 and valuation of 0.84 and 1.63 billion dollars in 2025, respectively.

In 2030, the potential socio-economic impact of this shipping method estimated at the amount of 3.04 billion dollars. The reduction potential from liquid bulk/tanker vessels are estimated to be $76 \mathrm{Mt}$ for the year 2020, and 541 for the year 2030 a potential 
decrease estimated between 15 and $54 \%$ of the amount of emitted carbon relative to the years in BAU state.

- Dry bulk vessels, the potential socio-economic impact of this shipping method estimated in 2020, at the amount of 2.2 billion dollars and in 2030, at the amount of 2.32 billion dollars.

The influential socio-economic areas are America and Asia-F.East, with a valuation of 0.57 and 0.97 billion dollars for 2020 and valuation of 0.64 and 1.24 billion dollars in 2025, respectively.

In 2030, the potential total social cost for this areas are at the amount of 2.32 billion dollars.

The reduction potential from dry bulk vessels are estimated to be $58 \mathrm{Mt}$ for the year 2020, and 412 for the year 2030 a potential decrease estimated between 15 and $54 \%$ of the amount of emitted carbon relative to the years in BAU state.

\section{Discussion, summary and conclusions}

Environmental resources have an economic value resulting from the indirect or direct benefits provided for the public. In attempting to estimate the resources' economic value, most estimates reflect only the negative benefits caused by changes in their current state.

In this research, we evaluate the environmental economic impact of shipping from the perspective of $\mathrm{CO}_{2}$ emissions and its potential reduction, by implementing METS. This trading scheme is based on the EU-ETS program with adjustment for the shipping industry needs.

First, we evaluate the socio-economic cost of carbon emission from the seaborne trade activity per borne ton criteria and per consumed ton fuel criteria in BAU and METS state.

Then we continue to evaluate the relative cost of socio-economic effect with regional segmentation, transportation modes and the expected effect on the shipping industry from the economic and environmental perspective.

Today the sea freight tariff mechanism is based on partial tariff that doesn't include the external costs arising from $\mathrm{CO}_{2}$ emission damage, which are a global problem regardless of the source and location the emissions were emitted. In an attempt to find an economic equilibrium that optimally includes all the constraints while taking into consideration the external costs, we selected a market-based approach, based on the motivation that the shipper must pay "the real" cost for the service that he provides (i.e., - sea freight). The use of a market-based method in this study, allows the producer's (i.e., - owner, vessel operator, etc.) surplus and that the market equilibrium point is economically efficient despite the constraints mentioned before, and eventually to maximize the consumer's (i.e., - shipper) surplus.

The IMO is currently responsible for resolving intergenerational and international conflicts relating to economic growth, globalization, and natural growth of populations against the principle of preserving the maritime environmental resources, which may be affected by sea freight activity or any involvement of any vessel. To date, this regulator intervened only in cases with high public awareness or cases that dramatically impacted the balance (i.e., - the oil tanker disaster Exxon Valdez, etc.). 
As a result of increasing environmental awareness, the IMO developed a mandatory technological tool, standards for new vessels (EEDI) and voluntary operational measures for ongoing shipping operators (SEEMP and EEOI), in order to assist them with the GHG abatement efforts.

The IMO's goal is to provide the vessel owners and operators with a set of tools to reduce the amount of greenhouse gas emissions while indicating the expected operational incentive from implementing these tools. It is worth mentioning that major part of the reduction potential is based on significantly reducing the sailing speed, an action that is often termed as "Slow Steaming", and in the past few years has become more common due to a sharp increase in the prices of fuel around the world.

"Slow Steaming" may result in decreases in FC, therefore achieving a double target of decreasing carbon emissions and fuel expenses. In the long run, it results in longer shipping times, higher levels of inventory at ports, higher stock at sea, higher financing demands, and higher insurance costs to the shipper. In our opinion, extended delivery times leads to an expected decrease in sea transportation level of attractiveness, although it remains one of the most efficient and environmentally transportation available today, in comparison to existing alternatives (i.e., - land, air).

High operation costs, inventory, and insurance costs, combined with long delivery times, have the potential to decrease the demands for sea freight services, which eventually could lead to the decrease of the amount of shipping carbon emissions. On the other hand, it has the potential to lead to an increase in carbon emissions on land through the logistical supply chain (i.e., - "carbon leaking"). Furthermore, if one considers the above-mentioned scenario, combining it with highly fuel prices, marginal abatement costs for emission reduction may have the potential to serve as a catalyst for the shipping industry, which in the long run may lead to an increase in cooperation between shipping companies (i.e., - merging between operators, bankruptcy, uniting lines, etc.). On the contrary, very low fuel prices have the potential to increase the demands for emissions trading in the shipping industry. Thus making METS mechanism more attractive for vessels operators from the basic approach of cost - benefit analysis, lack of need and the willingness to minimize operational cost. This is a result of high cost, effort and vast resources associated with required investments for new vessel design and innovative propulsion technologies.

This scenario is similar to the evolution experienced in the automobile industry in previous decades, ${ }^{2}$ which has strengthened a limited number of operators and manufactures, and as a result narrowed the level of competition (as well as the potential consumer's welfare).

Additionally, this scenario could lead to an actual decrease in economic activity of the smaller vessel operators or countries, which engaged in small trading volumes and have a negligible contribution or influence on the $\mathrm{CO}_{2}$ emission level.

On the other hand, a low marginal abatement cost combined with low emission reduction targets and high growth rates (FC) renders the maritime emission trading mechanism noneffective, and may prompt excess purchase (from vessel owners, operators, etc.) of emission permits instead of investing in reduction technologies that are estimated to be higher in cost.

This study shows, that implementing METS has the potential to bring the amount of carbon emissions close to the level of emissions in the reference year, for an annual reduction rate of $7 \%$ and more. 
While this achievement depends on low growth rates, it is possible to claim that in the situation with high costs for emission permits the polluter (vessel owners, operators, etc.) may have a different incentive to reduce emissions, in order to achieve the METS program's goals.

The results gathered from this study suggest that container shipping and the general cargo shipping are the most polluting means of international shipping while only carrying $18 \%$ of the world borne ton.

One could suggest in order to limit reduction costs, these costs should be calculated according to the borne ton criteria. This has the potential to lead to a selective "loading" of the reduction costs on the shipper, for example: sea freight of electronic goods (i.e., - computers and technology equipment) in container vessels are considered lightweight freight, but highly valuable. An attempt to implement calculation according to borne ton criteria could lead to higher payment request from the shipper in correlation to a similar sea freight of less valuable merchandise, reducing the consumer's surplus furthermore.

Due to its international nature, the shipping sector differs from other transportation modes, which are more subject to local laws. It requires a unique set of rules and standards in order to function properly and provide an appropriate response for the increasing demand.

Enforcement and monitoring of carbon emissions resulting from sea activity is considered one of the most complex regulations the shipping sector deals with today, (only few countries are signatories of the Kyoto Protocol). As a result, countries and interested parties have different concerns and object to the application of carbon regulations in the shipping industry under the pretext that the amount of emissions is insignificant, suggesting that regulation could lead to an increase in the sea freight cost and has the potential of igniting artificial economic crisis due to the international role of the shipping industry. Moreover, there is a reasonable concern for the feasibility of the "carbon leakage" phenomenon in case METS mechanism is implemented selectively, as a result of wide usage of "flag of convenience" in the shipping sector.

The shipping sector consists of a wide variety of international entities with different interests that are created in early stages such as: planning, building, operating, ownership, nationality of the staff, insurance concerns, banking, "bill of lading", etc. On the other hand, the origins of carbon emissions are of little significance as the damage these emissions cause are considered a global problem. A recent study found that the crowded sea routes have a high regionals impact on the ocean acidification phenomena (Hassellöv et al. 2013). Therefore, enforcement and monitoring action must be addressed at a global level, with no reference to the state of origin of the vessel operator or owner. While at the same time, in order to avoid unnecessary harm, in areas with insignificant economic impact (in terms of pollution), enforcement and monitoring efforts must take into account the relative economic contribution of the sea freight means and the areas of trade.

Although the idea suggested of IMO to enforce the international METS program is not in line with the current functionality of this international body, we think that IMO, as a regulator coordinator, does have economic tools for enforcement and compliance to protect the public interest (preserving the marine environmental resources): command and control, taxes, subsidies, etc. An overview of these tools reveals that these regulations are designed to determine acceptable behavior for the vessel operators/ owners (fencing in their area of activity). On the other hand, to achieve effective compliance the regulator requires significant information. These efforts for enforcement 
and monitoring are expected to bring additional external costs and more bureaucracy without any guarantee for effective emission reduction.

The tax solution is the simplest mode of enforcement. It does require the involvement of international law, but does not limit the permitted level of emissions, and leaves the decision in the operator's hands.

Subsidies operate as the mirror image of taxes, in which the operator receives an incentive payment for emission reduction. This tool has the potential to encourage reduction, but on the other hand requires a lot of funding. Furthermore, pre-allocation of subsidized reduction units can lead to increased activity, which means more emissions.

The METS can provide a "grandfather allocation", which are granted by the regulator to the polluter in a limited quota while allowing the regulator a control tool mechanism of the desired level of emissions by quantification means rather than the fixed price of emission permits.

The METS has proven feasible at a global level, able to cope with problems of information and uncertainty. It is regarded as one of the best options that does not require extensive legal activity. Furthermore, this tool has the potential to combine environmental and social concerns with low costs and economic growth.

To conclude, the purpose of this research is to generate an economic estimation of the maritime shipping impact on the environment, specifically focusing on the main GHG emissions (carbon) resulting from shipping activity. The goals of this research, as defined, dealt with the current sea freight tariff, considered a practical tariff that does not reflect the real social cost of sea freight. In this study we examined and attempted to identify the economic potential reduction rate that will ensure cost effective reduction while maintaining economic growth. We did so by implementing the METS mechanism and found its potential effectiveness.

The results and findings of this research, as presented until now, provide a reliable estimation tool for the decision-maker. Furthermore, the results can assist us to better understand the meaning of implementing the METS mechanism in the shipping industry and its expected economic impacts. Furthermore, these findings create a more transparent and informative tool for the decision-maker, while potentially minimizing the effects of changes on the consumer surplus for the shippers and help establish a more equitable society, socio-economically and environmentally.

International shipping services the global demand for food, energy, raw materials and finished products. It is one of the key figures in our world economy and plays a significant role in "globalizing" to the developing and emerging market countries and world economics. Seaborne trade continues to expand, thanks to increased growth in the emerging middle class population and to expected growth in urbanization rates. It is has operated for a long time without emission regulation and until recently it has not received significant attention, although it is a meaningful source of the accumulation of global carbon emissions.

Today high growth forecasts for the shipping industry combined with its role in "globalizing" leads us to the suggest that IMO must function as a regulator coordinator and take responsibility, enforce, and lead the international METS programs and GHG emission reduction.

Any resulting setback helps bring this industry to become a more meaningful contributor to the world GHG emission, carbon emission accumulation and the rise of the marginal social cost. 


\section{Endnotes}

${ }^{1} \mathrm{Mt}$ - Million tons

${ }^{2}$ Over the past 30 years, the automotive industry has invested significantly in research, design, and development of "greener" engines in an attempt to achieve better energy efficiency, lower fuel expenses, etc. High cost, together with other factors eventually led to a contraction in the number of operators (i.e., - car builders) either by mergers (e.g., - Volkswagen group merged with Porsche group - 2012, etc.) or due to bankruptcy.

\section{Appendix 1 Summary Table for International and for Global Shipping Scenarios}

Table 1 Scenarios and EUA prices

\begin{tabular}{lll}
\hline Low Bound & Best & High Bound \\
\hline $6.62 \$^{a}$ & $13.62 \$^{b}$ & $23.15 \$^{c}$ \\
\hline
\end{tabular}

Based on EUA Prices from Different Period of Time, Source: EU-ETS

a http://www.ecb.int/stats/exchange/eurofxref/html/eurofxref-graph-usd.en.html, Access on 11/09/13

${ }^{\mathrm{b}} \mathrm{http} / / /$ www.iata.org/publications/economics/Documents/EUETS-cost-briefing-march-2013.pdf, Access on 11/09/13

chttp://www.neded.org/files/international/exchange.pd, Access on 11/09/13

Table 2 T-test Table, Segmentation by Region and Scenario, International and Global Shipping BAU Vs. METS

\begin{tabular}{|c|c|c|c|c|c|c|c|c|c|c|}
\hline \multirow{2}{*}{$\begin{array}{l}\text { 2007-2030 } \\
\text { Scenarios } \\
\text { GR-RR-P }\end{array}$} & \multicolumn{5}{|c|}{$\begin{array}{l}\text { International Shipping } \\
\text { BAU Vs. METS }\end{array}$} & \multicolumn{5}{|c|}{$\begin{array}{l}\text { Global Shipping } \\
\text { BAU Vs. METS }\end{array}$} \\
\hline & $\begin{array}{l}\text { R-Squarec } \\
\text { (METS) }\end{array}$ & t Stat & $\begin{array}{l}\mathrm{P}(\mathrm{T}<=\mathrm{t}) \\
\text { one-tail }\end{array}$ & $\begin{array}{l}\text { t Critical } \\
\text { two-tail }\end{array}$ & $\begin{array}{l}\mathrm{P}(\mathrm{T}<=\mathrm{t}) \\
\text { two-tail }\end{array}$ & $\begin{array}{l}\text { R-Squared } \\
\text { (METS) }\end{array}$ & t Stat & $\begin{array}{l}\mathrm{P}(\mathrm{T}<=\mathrm{t}) \\
\text { one-tail }\end{array}$ & $\begin{array}{l}\text { t Critical } \\
\text { two-tail }\end{array}$ & $\begin{array}{l}\mathrm{P}(\mathrm{T}<=\mathrm{t}) \\
\text { two-tail }\end{array}$ \\
\hline $\begin{array}{l}\text { High-High- } \\
\text { High }\end{array}$ & -0.3708 & 1.7167 & 0.0649 & 2.3646 & 0.1297 & 0.4124 & -2.2226 & 0.0340 & 2.4469 & 0.0680 \\
\hline $\begin{array}{l}\text { High-Best- } \\
\text { Best }\end{array}$ & 0.0000 & -1.8412 & 0.0625 & 2.5706 & 0.1250 & 0.0134 & -1.8938 & 0.0535 & 2.4469 & 0.1071 \\
\hline $\begin{array}{l}\text { High-Low- } \\
\text { High }\end{array}$ & 0.8409 & -0.9469 & 0.1876 & 2.3646 & 0.3752 & 0.8118 & -0.9755 & 0.1809 & 2.3646 & 0.3618 \\
\hline $\begin{array}{l}\text { High-Low- } \\
\text { Low }\end{array}$ & 0.8409 & -0.9469 & 0.1876 & 2.3646 & 0.3752 & 0.8118 & -0.9755 & 0.1809 & 2.3646 & 0.3618 \\
\hline $\begin{array}{l}\text { Best-High- } \\
\text { High }\end{array}$ & 0.4982 & -2.3220 & 0.0296 & 2.4469 & 0.0593 & 0.5169 & -2.3800 & 0.0274 & 2.4469 & 0.0548 \\
\hline $\begin{array}{l}\text { Best-Best- } \\
\text { Best }\end{array}$ & 0.1012 & -1.1476 & 0.1389 & 2.2281 & 0.2779 & 0.1478 & -2.0490 & 0.0432 & 2.4469 & 0.0864 \\
\hline $\begin{array}{l}\text { Best-Low- } \\
\text { High }\end{array}$ & 0.7683 & -1.0341 & 0.1678 & 2.3646 & 0.3355 & 0.7127 & -1.0656 & 0.1610 & 2.3646 & 0.3220 \\
\hline $\begin{array}{l}\text { Best-Low- } \\
\text { Low }\end{array}$ & 0.7683 & -0.9658 & 0.1785 & 2.2281 & 0.3569 & 0.7127 & -1.0656 & 0.1610 & 2.3646 & 0.3220 \\
\hline $\begin{array}{l}\text { Low-High- } \\
\text { High }\end{array}$ & 0.6572 & -0.6001 & 0.2809 & 2.2281 & 0.5618 & 0.6765 & -2.7620 & 0.0110 & 2.2622 & 0.0220 \\
\hline $\begin{array}{l}\text { Low-Best- } \\
\text { Best }\end{array}$ & 0.4701 & -0.8955 & 0.1958 & 2.2281 & 0.3916 & 0.5219 & -2.4779 & 0.0212 & 2.3646 & 0.0423 \\
\hline $\begin{array}{l}\text { Low-Low- } \\
\text { High }\end{array}$ & 0.3557 & -1.3016 & 0.1171 & 2.3646 & 0.2343 & 0.2131 & -1.3787 & 0.1052 & 2.3646 & 0.2104 \\
\hline $\begin{array}{l}\text { Low-Low- } \\
\text { Low }\end{array}$ & 0.3557 & -1.3016 & 0.1171 & 2.3646 & 0.2343 & 0.2131 & -1.3787 & 0.1052 & 2.3646 & 0.2104 \\
\hline
\end{tabular}

Bold scenarios indicate there is a high correlation in result analysis, which allows us to conduct a proper estimation on the impact of implementing METS model in these various scenarios 
Table 3 Summary Table, Model Inputs - International Maritime Shipping

\begin{tabular}{|c|c|c|c|c|c|c|c|c|c|c|c|c|c|}
\hline \multirow{2}{*}{$\begin{array}{l}\text { Scenarios } \\
\text { (GR-RR-P) }\end{array}$} & \multirow[t]{2}{*}{ FC 2007} & \multirow[t]{2}{*}{$\mathrm{EF}$} & \multicolumn{7}{|c|}{ International shipping - Growth Rate (GR) } & \multicolumn{3}{|c|}{ Reduction Rate (RR) World Wide } & \multirow[t]{2}{*}{ Price $(P)$} \\
\hline & & & Middle East & Europe & America & Asia Arab & Asia F.East & Asia ISC & Africa & $2007-2014$ & $2015-2025$ & $2025-2030$ & \\
\hline High-High-High & 277 & 3.13 & $6.56 \%$ & $5.39 \%$ & $5.90 \%$ & $6.90 \%$ & $7.70 \%$ & $7.94 \%$ & $6.81 \%$ & $0.0 \%$ & $-10.0 \%$ & $-25.0 \%$ & $\$ 23.15$ \\
\hline High-Best-Best & 277 & 3.13 & $6.56 \%$ & $5.39 \%$ & $5.90 \%$ & $6.90 \%$ & $7.70 \%$ & $7.94 \%$ & $6.81 \%$ & $0.0 \%$ & $-7.0 \%$ & $-17.0 \%$ & $\$ 13.62$ \\
\hline High-Low-High & 277 & 3.13 & $6.56 \%$ & $5.39 \%$ & $5.90 \%$ & $6.90 \%$ & $7.70 \%$ & $7.94 \%$ & $6.81 \%$ & $0.0 \%$ & $-2.0 \%$ & $-10.0 \%$ & $\$ 23.15$ \\
\hline High-Low-Low & 277 & 3.13 & $6.56 \%$ & $5.39 \%$ & $5.90 \%$ & $6.90 \%$ & $7.70 \%$ & $7.94 \%$ & $6.81 \%$ & $0.0 \%$ & $-2.0 \%$ & $-10.0 \%$ & $\$ 6.62$ \\
\hline Best-High-High & 277 & 3.13 & $5.01 \%$ & $2.57 \%$ & $4.34 \%$ & $5.67 \%$ & $7.48 \%$ & $7.21 \%$ & $4.79 \%$ & $0.0 \%$ & $-10.00 \%$ & $-25.0 \%$ & $\$ 23.15$ \\
\hline Best-Best-Best & 277 & 3.13 & $5.01 \%$ & $2.57 \%$ & $4.34 \%$ & $5.67 \%$ & $7.48 \%$ & $7.21 \%$ & $4.79 \%$ & $0.0 \%$ & $-7.00 \%$ & $-17.00 \%$ & $\$ 13.62$ \\
\hline Best-Low-High & 277 & 3.13 & $5.01 \%$ & $2.57 \%$ & $4.34 \%$ & $5.67 \%$ & $7.48 \%$ & $7.21 \%$ & $4.79 \%$ & $0.0 \%$ & $-2.00 \%$ & $-10.0 \%$ & $\$ 23.15$ \\
\hline Best-Low-Low & 277 & 3.13 & $5.01 \%$ & $2.57 \%$ & $4.34 \%$ & $5.67 \%$ & $7.48 \%$ & $7.21 \%$ & $4.79 \%$ & $0.0 \%$ & $-2.00 \%$ & $-10.0 \%$ & $\$ 6.62$ \\
\hline Low-High-High & 277 & 3.13 & $3.20 \%$ & $1.70 \%$ & $3.20 \%$ & $3.20 \%$ & $5.10 \%$ & $6.40 \%$ & $4.79 \%$ & $0.0 \%$ & $-10.0 \%$ & $-25.0 \%$ & $\$ 23.15$ \\
\hline Low-Best-Best & 277 & 3.13 & $3.20 \%$ & $1.70 \%$ & $3.20 \%$ & $3.20 \%$ & $5.10 \%$ & $6.40 \%$ & $4.79 \%$ & $0.0 \%$ & $-7.0 \%$ & $-17.0 \%$ & $\$ 13.62$ \\
\hline Low-Low-High & 277 & 3.13 & $3.20 \%$ & $1.70 \%$ & $3.20 \%$ & $3.20 \%$ & $5.10 \%$ & $6.40 \%$ & $4.79 \%$ & $0.0 \%$ & $-2.0 \%$ & $-10.0 \%$ & $\$ 23.15$ \\
\hline Low-Low-Low & 277 & 3.13 & $3.20 \%$ & $1.70 \%$ & $3.20 \%$ & $3.20 \%$ & $5.10 \%$ & $6.40 \%$ & $4.79 \%$ & $0.0 \%$ & $-2.0 \%$ & $-10.0 \%$ & $\$ 6.62$ \\
\hline
\end{tabular}


Table 4 Summary Table, Model Inputs - Shipping Industry (Domestic and International)

\begin{tabular}{|c|c|c|c|c|c|c|c|c|c|c|c|c|c|}
\hline \multirow{2}{*}{$\begin{array}{l}\text { Scenarios } \\
\text { (GR-RR-P) }\end{array}$} & \multirow[t]{2}{*}{ FC 2007} & \multirow[t]{2}{*}{$\mathrm{EF}$} & \multicolumn{7}{|c|}{ Global shipping - Growth Rate (GR) } & \multicolumn{3}{|c|}{ Reduction Rate (RR) World Wide } & \multirow[t]{2}{*}{ Price $(P)$} \\
\hline & & & Middle East & Europe & America & Asia Arab & Asia F.East & Asia ISC & Africa & 2007-2014 & $2015-2025$ & $2025-2030$ & \\
\hline High-High-High & 333 & 3.13 & $6.43 \%$ & $6.43 \%$ & $6.43 \%$ & $6.43 \%$ & $6.43 \%$ & $6.43 \%$ & $6.43 \%$ & $0.0 \%$ & $-10.0 \%$ & $-25.0 \%$ & $\$ 23.15$ \\
\hline High-Best-Best & 333 & 3.13 & $6.43 \%$ & $6.43 \%$ & $6.43 \%$ & $6.43 \%$ & $6.43 \%$ & $6.43 \%$ & $6.43 \%$ & $0.0 \%$ & $-7.0 \%$ & $-17.0 \%$ & $\$ 13.62$ \\
\hline High-Low-High & 333 & 3.13 & $6.43 \%$ & $6.43 \%$ & $6.43 \%$ & $6.43 \%$ & $6.43 \%$ & $6.43 \%$ & $6.43 \%$ & $0.0 \%$ & $-2.0 \%$ & $-10.0 \%$ & $\$ 23.15$ \\
\hline High-Low-Low & 333 & 3.13 & $6.43 \%$ & $6.43 \%$ & $6.43 \%$ & $6.43 \%$ & $6.43 \%$ & $6.43 \%$ & $6.43 \%$ & $0.0 \%$ & $-2.0 \%$ & $-10.0 \%$ & $\$ 6.62$ \\
\hline Best-High-High & 333 & 3.13 & $5.53 \%$ & $5.53 \%$ & $5.53 \%$ & $5.53 \%$ & $5.53 \%$ & $5.53 \%$ & $5.53 \%$ & $0.0 \%$ & $-10.00 \%$ & $-25.0 \%$ & $\$ 23.15$ \\
\hline Best-Best-Best & 333 & 3.13 & $5.53 \%$ & $5.53 \%$ & $5.53 \%$ & $5.53 \%$ & $5.53 \%$ & $5.53 \%$ & $5.53 \%$ & $0.0 \%$ & $-7.00 \%$ & $-17.00 \%$ & $\$ 13.62$ \\
\hline Best-Low-High & 333 & 3.13 & $5.53 \%$ & $5.53 \%$ & $5.53 \%$ & $5.53 \%$ & $5.53 \%$ & $5.53 \%$ & $5.53 \%$ & $0.0 \%$ & $-2.00 \%$ & $-10.0 \%$ & $\$ 23.15$ \\
\hline Best-Low-Low & 333 & 3.13 & $5.53 \%$ & $5.53 \%$ & $5.53 \%$ & $5.53 \%$ & $5.53 \%$ & $5.53 \%$ & $5.53 \%$ & $0.0 \%$ & $-2.00 \%$ & $-10.0 \%$ & $\$ 6.62$ \\
\hline Low-High-High & 333 & 3.13 & $3.60 \%$ & $3.60 \%$ & $3.60 \%$ & $3.60 \%$ & $3.60 \%$ & $3.60 \%$ & $3.60 \%$ & $0.0 \%$ & $-10.0 \%$ & $-25.0 \%$ & $\$ 23.15$ \\
\hline Low-Best-Best & 333 & 3.13 & $3.60 \%$ & $3.60 \%$ & $3.60 \%$ & $3.60 \%$ & $3.60 \%$ & $3.60 \%$ & $3.60 \%$ & $0.0 \%$ & $-7.0 \%$ & $-17.0 \%$ & $\$ 13.62$ \\
\hline Low-Low-High & 333 & 3.13 & $3.60 \%$ & $3.60 \%$ & $3.60 \%$ & $3.60 \%$ & $3.60 \%$ & $3.60 \%$ & $3.60 \%$ & $0.0 \%$ & $-2.0 \%$ & $-10.0 \%$ & $\$ 23.15$ \\
\hline Low-Low-Low & 333 & 3.13 & $3.60 \%$ & $3.60 \%$ & $3.60 \%$ & $3.60 \%$ & $3.60 \%$ & $3.60 \%$ & $3.60 \%$ & $0.0 \%$ & $-2.0 \%$ & $-10.0 \%$ & $\$ 6.62$ \\
\hline
\end{tabular}




\section{Appendix 2 Carbon emission segmentation according to regions \& means of transport}

Table 5 Segmentation of Carbon Emission, by Transportation Mode and Region and Between Region - International Shipping

\begin{tabular}{|c|c|c|c|c|c|}
\hline \multicolumn{6}{|l|}{ International Shipping } \\
\hline Trade Area & D.Bulk & L.Bulk & Neo.Bulk & Container & Total $\mathrm{CO}_{2}(\mathrm{Mt})$ \\
\hline Tot. Middle East Seaborne & 8.39 & 6.98 & 16.10 & 16.99 & 48.45 \\
\hline Middle East & 1.82 & 2.20 & 3.55 & 2.92 & 10.49 \\
\hline Europe & 1.11 & 1.75 & 4.45 & 4.29 & 11.60 \\
\hline America & 3.97 & 0.32 & 3.60 & 3.28 & 11.17 \\
\hline Asia - Arab & 0.15 & 2.41 & 0.92 & 0.83 & 4.30 \\
\hline Asia - F.East & 0.47 & 0.25 & 2.70 & 4.81 & 8.23 \\
\hline Asia - ISC & 0.19 & 0.03 & 0.42 & 0.50 & 1.14 \\
\hline Africa & 0.67 & 0.02 & 0.46 & 0.35 & 1.51 \\
\hline Tot. Europe Seaborne & 31.84 & 30.90 & 46.37 & 48.54 & 157.65 \\
\hline Europe & 1.30 & 2.08 & 2.58 & 3.68 & 9.64 \\
\hline Middle East & 1.87 & 8.91 & 7.04 & 3.26 & 21.09 \\
\hline America & 18.47 & 2.83 & 18.46 & 15.44 & 55.20 \\
\hline Asia - Arab & 0.26 & 13.09 & 1.12 & 1.29 & 15.75 \\
\hline Asia - F.East & 2.41 & 0.45 & 9.64 & 19.56 & 32.06 \\
\hline Asia - ISC & 0.47 & 0.10 & 1.60 & 1.88 & 4.05 \\
\hline Africa & 7.07 & 3.45 & 5.92 & 3.42 & 19.86 \\
\hline Tot. America Seaborne & 22.51 & 60.99 & 74.61 & 79.31 & 237.42 \\
\hline America & 1.67 & 3.25 & 4.53 & 2.97 & 12.42 \\
\hline Middle East & 2.18 & 9.81 & 14.42 & 17.55 & 43.96 \\
\hline Europe & 15.77 & 27.24 & 32.23 & 23.33 & 98.57 \\
\hline Asia - Arab & 0.14 & 11.10 & 0.22 & 0.75 & 12.21 \\
\hline Asia - F.East & 1.88 & 1.36 & 21.67 & 31.85 & 56.77 \\
\hline Asia - ISC & 0.12 & 0.12 & 0.55 & 1.87 & 2.67 \\
\hline Africa & 0.75 & 8.10 & 0.98 & 0.99 & 10.82 \\
\hline Tot. Asia. Arab Seaborne & 4.99 & 1.23 & 12.79 & 12.30 & 31.31 \\
\hline Asia - Arab & 0.96 & 0.30 & 3.26 & 1.86 & 6.38 \\
\hline Middle East & 0.96 & 0.13 & 2.66 & 3.82 & 7.56 \\
\hline Europe & 1.68 & 0.14 & 1.62 & 1.28 & 4.72 \\
\hline America & 0.15 & 0.13 & 0.30 & 0.50 & 1.09 \\
\hline Asia - F.East & 0.65 & 0.27 & 3.52 & 3.56 & 8.00 \\
\hline Asia - ISC & 0.49 & 0.22 & 1.06 & 0.95 & 2.72 \\
\hline Africa & 0.10 & 0.04 & 0.37 & 0.33 & 0.84 \\
\hline Tot. Asia. F.East Seaborne & 54.55 & 70.29 & 96.68 & 114.10 & 335.61 \\
\hline Asia - F.East & 3.41 & 1.62 & 8.12 & 2.92 & 16.07 \\
\hline Middle East & 1.27 & 0.94 & 6.28 & 12.91 & 21.41 \\
\hline Europe & 19.62 & 2.06 & 29.98 & 24.08 & 75.75 \\
\hline America & 0.62 & 44.77 & 1.30 & 2.24 & 48.93 \\
\hline Asia - Arab & 22.17 & 17.41 & 43.90 & 68.98 & 152.46 \\
\hline Asia - ISC & 4.75 & 0.45 & 2.02 & 1.47 & 8.69 \\
\hline Africa & 2.71 & 3.03 & 5.08 & 1.49 & 12.31 \\
\hline
\end{tabular}


Table 5 Segmentation of Carbon Emission, by Transportation Mode and Region and Between Region - International Shipping (Continued)

\begin{tabular}{llllll}
\hline Tot. Asia. ISC Seaborne & 4.83 & 6.00 & 12.29 & 6.95 & 30.07 \\
Asia - ISC & 0.62 & 0.17 & 1.51 & 0.46 & 2.77 \\
Middle East & 0.47 & 0.22 & 1.98 & 1.19 & 3.84 \\
Europe & 0.63 & 0.38 & 2.09 & 1.01 & 4.11 \\
America & 0.52 & 3.36 & 0.98 & 0.69 & 5.55 \\
Asia - ARAB & 1.95 & 1.14 & 4.36 & 2.94 & 10.39 \\
Asia - F.East & 0.22 & 0.04 & 0.32 & 0.31 & 0.88 \\
Africa & 0.44 & 0.69 & 1.06 & 0.35 & 2.54 \\
Tot. Africa Seaborne & 3.81 & 3.95 & 8.20 & 10.54 & 26.50 \\
Africa & 0.47 & 0.08 & 0.47 & 0.66 & 1.68 \\
Middle East & 0.74 & 0.53 & 3.23 & 4.44 & 8.94 \\
Europe & 0.97 & 0.19 & 1.49 & 1.33 & 3.98 \\
America & 0.16 & 2.64 & 0.32 & 0.65 & 3.77 \\
Asia - ARAB & 1.02 & 0.20 & 1.57 & 2.31 & 5.10 \\
Asia - F.East & 0.23 & 0.07 & 0.54 & 0.51 & 1.36 \\
Asia - ISC & 0.22 & 0.23 & 0.58 & 0.63 & 1.67 \\
Grand Total & 130.92 & 180.34 & 267.04 & 288.71 & 867.01 \\
\hline Fom this stuy, based & 1.23 & & \\
\hline
\end{tabular}

From this study, based on: IHS Global Insight Inc. (2010, May) 


\section{Appendix 3 Carbon emitted potential ratio, segmentation by region and transportation mode}

Table 6 Carbon Emitted Ratio, Segmentation by Region, Between Regions and Transportation Mode, International Shipping

\begin{tabular}{|c|c|c|c|c|}
\hline \\
\hline \multicolumn{5}{|c|}{$\begin{array}{l}\text { International shipping } \\
\text { Trade Area }\end{array}$} \\
\hline Middle East & $22.74 \%$ & $18.02 \%$ & $30.66 \%$ & $28.58 \%$ \\
\hline Middle East & $4.93 \%$ & $5.68 \%$ & $6.76 \%$ & $4.91 \%$ \\
\hline Europe & $3.01 \%$ & $4.52 \%$ & $8.48 \%$ & $7.22 \%$ \\
\hline America & $10.77 \%$ & $0.82 \%$ & $6.85 \%$ & $5.52 \%$ \\
\hline Asia - ARAB & $0.40 \%$ & $6.23 \%$ & $1.75 \%$ & $1.39 \%$ \\
\hline Asia - F.East & $1.29 \%$ & $0.64 \%$ & $5.15 \%$ & $8.09 \%$ \\
\hline Asia - ISC & $0.51 \%$ & $0.07 \%$ & $0.80 \%$ & $0.85 \%$ \\
\hline Africa & $1.83 \%$ & $0.06 \%$ & $0.87 \%$ & $0.60 \%$ \\
\hline Europe & $25.69 \%$ & $23.74 \%$ & $26.28 \%$ & $24.29 \%$ \\
\hline Middle East & $1.05 \%$ & $1.60 \%$ & $1.46 \%$ & $1.84 \%$ \\
\hline Europe & $1.51 \%$ & $6.85 \%$ & $3.99 \%$ & $1.63 \%$ \\
\hline America & $14.90 \%$ & $2.17 \%$ & $10.46 \%$ & $7.73 \%$ \\
\hline Asia - ARAB & $0.21 \%$ & $10.06 \%$ & $0.63 \%$ & $0.64 \%$ \\
\hline Asia - F.East & $1.94 \%$ & $0.34 \%$ & $5.46 \%$ & $9.79 \%$ \\
\hline Asia - ISC & $0.38 \%$ & $0.07 \%$ & $0.91 \%$ & $0.94 \%$ \\
\hline Africa & $5.70 \%$ & $2.65 \%$ & $3.36 \%$ & $1.71 \%$ \\
\hline America & $12.35 \%$ & $31.88 \%$ & $28.77 \%$ & $27.00 \%$ \\
\hline Middle East & $0.92 \%$ & $1.70 \%$ & $1.75 \%$ & $1.01 \%$ \\
\hline Europe & $1.20 \%$ & $5.13 \%$ & $5.56 \%$ & $5.98 \%$ \\
\hline America & $8.66 \%$ & $14.24 \%$ & $12.43 \%$ & $7.94 \%$ \\
\hline Asia - ARAB & $0.08 \%$ & $5.80 \%$ & $0.08 \%$ & $0.25 \%$ \\
\hline Asia - F.East & $1.03 \%$ & $0.71 \%$ & $8.36 \%$ & $10.84 \%$ \\
\hline Asia - ISC & $0.07 \%$ & $0.07 \%$ & $0.21 \%$ & $0.64 \%$ \\
\hline Africa & $0.41 \%$ & $4.23 \%$ & $0.38 \%$ & $0.34 \%$ \\
\hline Asia - ARAB & $21.91 \%$ & $5.15 \%$ & $39.44 \%$ & $33.50 \%$ \\
\hline Middle East & $4.24 \%$ & $1.26 \%$ & $10.04 \%$ & $5.07 \%$ \\
\hline Europe & $4.20 \%$ & $0.55 \%$ & $8.19 \%$ & $10.40 \%$ \\
\hline America & $7.36 \%$ & $0.58 \%$ & $5.00 \%$ & $3.48 \%$ \\
\hline Asia - ARAB & $0.67 \%$ & $0.56 \%$ & $0.93 \%$ & $1.36 \%$ \\
\hline Asia - F.East & $2.87 \%$ & $1.11 \%$ & $10.84 \%$ & $9.70 \%$ \\
\hline Asia - ISC & $2.15 \%$ & $0.92 \%$ & $3.28 \%$ & $2.58 \%$ \\
\hline Africa & $0.43 \%$ & $0.17 \%$ & $1.15 \%$ & $0.90 \%$ \\
\hline Asia - F.East & $20.96 \%$ & $25.73 \%$ & $26.11 \%$ & $27.20 \%$ \\
\hline Middle East & $1.31 \%$ & $0.59 \%$ & $2.19 \%$ & $0.70 \%$ \\
\hline Europe & $0.49 \%$ & $0.35 \%$ & $1.70 \%$ & $3.08 \%$ \\
\hline America & $7.54 \%$ & $0.76 \%$ & $8.09 \%$ & $5.74 \%$ \\
\hline Asia - ARAB & $0.24 \%$ & $16.39 \%$ & $0.35 \%$ & $0.53 \%$ \\
\hline Asia - F.East & $8.52 \%$ & $6.37 \%$ & $11.85 \%$ & $16.45 \%$ \\
\hline Asia - ISC & $1.83 \%$ & $0.16 \%$ & $0.54 \%$ & $0.35 \%$ \\
\hline Africa & $1.04 \%$ & $1.11 \%$ & $1.37 \%$ & $0.35 \%$ \\
\hline
\end{tabular}


Table 6 Carbon Emitted Ratio, Segmentation by Region, Between Regions and Transportation Mode, International Shipping (Continued)

\begin{tabular}{cllll}
\hline Asia - ISC & $20.55 \%$ & $24.34 \%$ & $36.76 \%$ & $18.35 \%$ \\
Middle East & $2.63 \%$ & $0.70 \%$ & $4.53 \%$ & $1.22 \%$ \\
Europe & $1.98 \%$ & $0.88 \%$ & $5.91 \%$ & $3.13 \%$ \\
America & $2.66 \%$ & $1.54 \%$ & $6.25 \%$ & $2.68 \%$ \\
Asia - ARAB & $2.20 \%$ & $13.64 \%$ & $2.92 \%$ & $1.82 \%$ \\
Asia - F.East & $8.30 \%$ & $4.62 \%$ & $13.02 \%$ & $7.77 \%$ \\
Asia - ISC & $0.92 \%$ & $0.17 \%$ & $0.94 \%$ & $0.81 \%$ \\
Africa & $1.86 \%$ & $2.80 \%$ & $3.18 \%$ & $0.91 \%$ \\
Africa & $19.20 \%$ & $18.91 \%$ & $28.99 \%$ & $32.90 \%$ \\
Middle East & $2.38 \%$ & $0.37 \%$ & $1.66 \%$ & $2.07 \%$ \\
Europe & $3.72 \%$ & $2.55 \%$ & $11.40 \%$ & $13.87 \%$ \\
America & $4.88 \%$ & $0.90 \%$ & $5.27 \%$ & $4.15 \%$ \\
Asia - ARAB & $0.80 \%$ & $12.65 \%$ & $1.13 \%$ & $2.02 \%$ \\
Asia - F.East & $5.14 \%$ & $0.97 \%$ & $5.53 \%$ & $7.22 \%$ \\
Asia - ISC & $1.17 \%$ & $0.34 \%$ & $1.93 \%$ & $1.59 \%$ \\
Africa & $1.11 \%$ & $1.12 \%$ & $2.06 \%$ & $1.96 \%$ \\
Total Trade & $19.56 \%$ & $25.66 \%$ & $28.03 \%$ & $26.76 \%$ \\
\hline Ficm $\%$ & & \\
\hline
\end{tabular}

From this study, based on: IHS Global Insight Inc. (2010, May) 


\section{Appendix 4 Seaborne ton by regional segmentation and transportation mode}

Table 7 Seaborne ton by Regional Segmentation and Transportation Mode, years 1997-2007 International Shipping (Average Ratio)

\begin{tabular}{|c|c|c|c|c|c|}
\hline \multicolumn{6}{|c|}{ International Shipping } \\
\hline Trade Area & D.Bulk (\%) & L.Bulk (\%) & Neo.Bulk (\%) & Container (\%) & Total (\%) \\
\hline Middle East & $2.2 \%$ & $1.9 \%$ & $0.4 \%$ & $0.7 \%$ & $5.1 \%$ \\
\hline Middle East & $0.5 \%$ & $0.6 \%$ & $0.1 \%$ & $0.1 \%$ & \\
\hline Europe & $0.3 \%$ & $0.5 \%$ & $0.1 \%$ & $0.2 \%$ & \\
\hline America & $1.0 \%$ & $0.1 \%$ & $0.1 \%$ & $0.1 \%$ & \\
\hline Asia - Arab & $0.0 \%$ & $0.6 \%$ & $0.0 \%$ & $0.0 \%$ & \\
\hline Asia - F.East & $0.1 \%$ & $0.1 \%$ & $0.1 \%$ & $0.2 \%$ & \\
\hline Asia - ISC & $0.0 \%$ & $0.0 \%$ & $0.0 \%$ & $0.0 \%$ & \\
\hline Africa & $0.2 \%$ & $0.0 \%$ & $0.0 \%$ & $0.0 \%$ & \\
\hline Europe & $8.4 \%$ & $8.2 \%$ & $1.0 \%$ & $2.0 \%$ & $19.6 \%$ \\
\hline Middle East & $0.3 \%$ & $0.6 \%$ & $0.1 \%$ & $0.2 \%$ & \\
\hline Europe & $0.5 \%$ & $2.4 \%$ & $0.2 \%$ & $0.1 \%$ & \\
\hline America & $4.9 \%$ & $0.7 \%$ & $0.4 \%$ & $0.6 \%$ & \\
\hline Asia - Arab & $0.1 \%$ & $3.5 \%$ & $0.0 \%$ & $0.1 \%$ & \\
\hline Asia - F.East & $0.6 \%$ & $0.1 \%$ & $0.2 \%$ & $0.8 \%$ & \\
\hline Asia - ISC & $0.1 \%$ & $0.0 \%$ & $0.0 \%$ & $0.1 \%$ & \\
\hline Africa & $1.9 \%$ & $0.9 \%$ & $0.1 \%$ & $0.1 \%$ & \\
\hline America & $5.9 \%$ & $16.2 \%$ & $1.6 \%$ & $3.2 \%$ & $27.0 \%$ \\
\hline Middle East & $0.4 \%$ & $0.9 \%$ & $0.1 \%$ & $0.1 \%$ & \\
\hline Europe & $0.6 \%$ & $2.6 \%$ & $0.3 \%$ & $0.7 \%$ & \\
\hline America & $4.2 \%$ & $7.2 \%$ & $0.7 \%$ & $1.0 \%$ & \\
\hline Asia - Arab & $0.0 \%$ & $2.9 \%$ & $0.0 \%$ & $0.0 \%$ & \\
\hline Asia - F.East & $0.5 \%$ & $0.4 \%$ & $0.5 \%$ & $1.3 \%$ & \\
\hline Asia - ISC & $0.0 \%$ & $0.0 \%$ & $0.0 \%$ & $0.1 \%$ & \\
\hline Africa & $0.2 \%$ & $2.1 \%$ & $0.0 \%$ & $0.0 \%$ & \\
\hline Asia - Arab & $1.3 \%$ & $0.3 \%$ & $0.3 \%$ & $0.5 \%$ & $2.4 \%$ \\
\hline Middle East & $0.3 \%$ & $0.1 \%$ & $0.1 \%$ & $0.1 \%$ & \\
\hline Europe & $0.3 \%$ & $0.0 \%$ & $0.1 \%$ & $0.2 \%$ & \\
\hline America & $0.4 \%$ & $0.0 \%$ & $0.0 \%$ & $0.1 \%$ & \\
\hline Asia - Arab & $0.0 \%$ & $0.0 \%$ & $0.0 \%$ & $0.0 \%$ & \\
\hline Asia - F.East & $0.2 \%$ & $0.1 \%$ & $0.1 \%$ & $0.1 \%$ & \\
\hline Asia - ISC & $0.1 \%$ & $0.1 \%$ & $0.0 \%$ & $0.0 \%$ & \\
\hline Africa & $0.0 \%$ & $0.0 \%$ & $0.0 \%$ & $0.0 \%$ & \\
\hline Asia - F.East & $14.4 \%$ & $18.6 \%$ & $2.1 \%$ & $4.7 \%$ & $39.8 \%$ \\
\hline Middle East & $0.9 \%$ & $0.4 \%$ & $0.2 \%$ & $0.1 \%$ & \\
\hline Europe & $0.3 \%$ & $0.3 \%$ & $0.1 \%$ & $0.5 \%$ & \\
\hline America & $5.2 \%$ & $0.5 \%$ & $0.7 \%$ & $1.0 \%$ & \\
\hline Asia - Arab & $0.2 \%$ & $11.9 \%$ & $0.0 \%$ & $0.1 \%$ & \\
\hline Asia - F.East & $5.8 \%$ & $4.6 \%$ & $1.0 \%$ & $2.8 \%$ & \\
\hline Asia - ISC & $1.3 \%$ & $0.1 \%$ & $0.0 \%$ & $0.1 \%$ & \\
\hline Africa & $0.7 \%$ & $0.8 \%$ & $0.1 \%$ & $0.1 \%$ & \\
\hline Asia - ISC & $1.3 \%$ & $1.6 \%$ & $0.3 \%$ & $0.3 \%$ & $3.4 \%$ \\
\hline
\end{tabular}


Table 7 Seaborne ton by Regional Segmentation and Transportation Mode, years 1997-2007 International Shipping (Average Ratio) (Continued)

\begin{tabular}{lllll}
\hline Middle East & $0.2 \%$ & $0.0 \%$ & $0.0 \%$ & $0.0 \%$ \\
Europe & $0.1 \%$ & $0.1 \%$ & $0.0 \%$ & $0.0 \%$ \\
America & $0.2 \%$ & $0.1 \%$ & $0.0 \%$ & $0.0 \%$ \\
Asia - Arab & $0.1 \%$ & $0.9 \%$ & $0.0 \%$ & $0.0 \%$ \\
Asia - F.East & $0.5 \%$ & $0.3 \%$ & $0.1 \%$ & $0.1 \%$ \\
Asia - ISC & $0.1 \%$ & $0.0 \%$ & $0.0 \%$ & $0.0 \%$ \\
Africa & $0.1 \%$ & $0.2 \%$ & $0.0 \%$ & $0.0 \%$ \\
Africa & $1.0 \%$ & $1.0 \%$ & $0.2 \%$ & $0.4 \%$ \\
Middle East & $0.1 \%$ & $0.0 \%$ & $0.0 \%$ & $0.0 \%$ \\
Europe & $0.2 \%$ & $0.1 \%$ & $0.1 \%$ & $0.2 \%$ \\
America & $0.3 \%$ & $0.1 \%$ & $0.0 \%$ & $0.1 \%$ \\
Asia - Arab & $0.0 \%$ & $0.7 \%$ & $0.0 \%$ & $0.0 \%$ \\
Asia - F.East & $0.3 \%$ & $0.1 \%$ & $0.0 \%$ & $0.1 \%$ \\
Asia - ISC & $0.1 \%$ & $0.0 \%$ & $0.0 \%$ & $0.0 \%$ \\
Africa & $0.1 \%$ & $0.1 \%$ & $0.0 \%$ & $0.0 \%$ \\
Total Trade & $34.5 \%$ & $47.8 \%$ & $5.9 \%$ & $11.8 \%$ \\
\hline
\end{tabular}

From this study, based on: IHS Global Insight Inc. (2010, May)

\section{Appendix 5 Model results (International Shipping)}

Table 8 External Costs, by Scenarios BAU vs. METS - International Shipping, 2015

\begin{tabular}{|c|c|c|c|c|c|c|c|c|c|c|}
\hline \multicolumn{11}{|c|}{ International Shipping } \\
\hline \multirow{2}{*}{$\begin{array}{l}2015 \\
\text { Scenarios } \\
\text { GR-RR-P }\end{array}$} & \multicolumn{2}{|c|}{$\begin{array}{l}\text { BAU (Without } \\
\text { Reduction) }\end{array}$} & \multicolumn{2}{|c|}{ METS - Implemented } & \multicolumn{2}{|c|}{ Outcome } & \multirow{2}{*}{$\begin{array}{l}\mathrm{FC} \\
(\mathrm{Mt})\end{array}$} & \multirow{2}{*}{$\begin{array}{l}\text { MAC } \\
\text { t) TAC/FC } \\
(\$ / t)\end{array}$} & \multirow{2}{*}{$\begin{array}{l}\text { MSC (BAU) } \\
\text { TSC/FC } \\
\text { (\$/t) }\end{array}$} & \multirow{2}{*}{$\begin{array}{l}\text { MSC (METS) } \\
\text { TSC/FC } \\
(\$ / t)\end{array}$} \\
\hline & $\begin{array}{l}\text { TSC } \\
(\$ M)\end{array}$ & $\begin{array}{l}\mathrm{CO}_{2}- \\
\text { Emitted (Mt) }\end{array}$ & $\begin{aligned} & \text { TAC } \\
\Rightarrow & (\$ M)\end{aligned}$ & $\begin{array}{l}\mathrm{CO}_{2} \text { - } \\
\text { Abetment (Mt) }\end{array}$ & $\begin{array}{l}\text { TD } \\
(\$ M)\end{array}$ & $\begin{array}{l}\mathrm{CO}_{2} \\
\text { (Mt) }\end{array}$ & & & & \\
\hline $\begin{array}{l}\text { High-High- } \\
\text { High }\end{array}$ & $\$ 33,731$ & 1,457 & $\$ 3,160$ & $0-137$ & $\$ 30,571$ & 1,321 & 466 & $\$ 6.79$ & $\$ 72.46$ & $\$ 65.67$ \\
\hline $\begin{array}{l}\text { High-Best- } \\
\text { Best }\end{array}$ & $\$ 19,845$ & 1,457 & $\$ 1,302$ & -96 & $\$ 18,544$ & $+1,362$ & 2466 & $\$ 2.80$ & $\$ 42.63$ & $\$ 39.83$ \\
\hline $\begin{array}{l}\text { High-Low- } \\
\text { High }\end{array}$ & $\$ 33,731$ & 1,457 & $\$ 632$ & -27 & $\$ 33,099$ & 1,430 & 466 & $\$ 1.36$ & $\$ 72.46$ & $\$ 71.10$ \\
\hline $\begin{array}{l}\text { High-Low- } \\
\text { Low }\end{array}$ & $\$ 9,646$ & 1,457 & $\$ 181$ & -27 & $\$ 9,465$ & 1,430 & 466 & $\$ 0.39$ & $\$ 20.72$ & $\$ 20.33$ \\
\hline $\begin{array}{l}\text { Best-High- } \\
\text { High }\end{array}$ & $\$ 30,915$ & 1,335 & $\$ 2,926$ & -126 & $\$ 27,989$ & 1,209 & 927 & $\$ 6.86$ & $\$ 72.46$ & $\$ 65.60$ \\
\hline $\begin{array}{l}\text { Best-Best- } \\
\text { Best }\end{array}$ & $\$ 18,188$ & 1,335 & $\$ 1,205$ & -88 & $\$ 16,983$ & 1,247 & 7427 & $\$ 2.82$ & $\$ 42.63$ & $\$ 39.81$ \\
\hline $\begin{array}{l}\text { Best-Low- } \\
\text { High }\end{array}$ & $\$ 30,915$ & 1,335 & $\$ 585$ & -25 & $\$ 30,330$ & 1,310 & 427 & $\$ 1.37$ & $\$ 72.46$ & $\$ 71.09$ \\
\hline $\begin{array}{l}\text { Best-Low- } \\
\text { Low }\end{array}$ & $\$ 8,840$ & 1,335 & $\$ 167$ & -25 & $\$ 8,673$ & 1,310 & 427 & $\$ 0.39$ & $\$ 20.72$ & $\$ 20.33$ \\
\hline $\begin{array}{l}\text { Low-High- } \\
\text { High }\end{array}$ & $\$ 27,123$ & 1,172 & $\$ 2,611$ & -113 & $\$ 24,512$ & 1,059 & 9374 & $\$ 6.97$ & $\$ 72.46$ & $\$ 65.49$ \\
\hline $\begin{array}{l}\text { Low-Best- } \\
\text { Best }\end{array}$ & $\$ 15,957$ & 1,172 & $\$ 1,075$ & -79 & $\$ 14,882$ & 1,093 & 3374 & $\$ 2.87$ & $\$ 42.63$ & $\$ 39.76$ \\
\hline $\begin{array}{l}\text { Low-Low- } \\
\text { High }\end{array}$ & $\$ 27,123$ & 1,172 & $\$ 522$ & -23 & $\$ 26,601$ & 1,149 & 9374 & $\$ 1.39$ & $\$ 72.46$ & $\$ 71.06$ \\
\hline $\begin{array}{l}\text { Low-Low- } \\
\text { Low }\end{array}$ & $\$ 7,756$ & 1,172 & $\$ 149$ & -23 & $\$ 7,607$ & 1,149 & 9374 & $\$ 0.40$ & $\$ 20.72$ & $\$ 20.32$ \\
\hline
\end{tabular}


Table 9 External Costs, by Scenarios BAU vs. METS - International Shipping, 2020

\begin{tabular}{|c|c|c|c|c|c|c|c|c|c|c|}
\hline \multicolumn{11}{|c|}{ International Shipping } \\
\hline \multirow{2}{*}{$\begin{array}{l}2020 \\
\text { Scenarios } \\
\text { GR-RR-P }\end{array}$} & \multicolumn{2}{|c|}{$\begin{array}{l}\text { BAU (Without } \\
\text { Reduction) }\end{array}$} & \multicolumn{2}{|c|}{ METS - Implemented } & \multicolumn{2}{|c|}{ Outcome } & \multirow[t]{2}{*}{$\begin{array}{l}\mathrm{FC} \\
(\mathrm{Mt})\end{array}$} & \multirow{2}{*}{$\begin{array}{l}\text { MAC } \\
\text { TAC/FC } \\
(\$ / t)\end{array}$} & \multirow{2}{*}{$\begin{array}{l}\text { MSC } \\
\text { (BAU) } \\
\text { TSC/FC } \\
(\$ / t)\end{array}$} & \multirow{2}{*}{$\begin{array}{l}\text { MSC } \\
\text { (METS) } \\
\text { TSC/FC } \\
(\$ / t)\end{array}$} \\
\hline & $\begin{array}{l}\text { TSC } \\
(\text { SM) }\end{array}$ & $\begin{array}{l}\mathrm{CO}_{2} \text { - } \\
\text { Emitted } \\
\text { (Mt) }\end{array}$ & $\begin{array}{l}\text { TAC } \\
(\$ M)\end{array}$ & $\begin{array}{l}\mathrm{CO}_{2} \text { - } \\
\text { Abetment } \\
\text { (Mt) }\end{array}$ & $\begin{array}{l}\text { TD } \\
(\$ M)\end{array}$ & $\begin{array}{l}\mathrm{CO}_{2} \\
(\mathrm{Mt})\end{array}$ & & & & \\
\hline $\begin{array}{l}\text { High-High- } \\
\text { High }\end{array}$ & $\$ 51,462$ & 2,021 & $\$ 22,935$ & -901 & $\$ 28,527$ & 1,120 & 646 & $\$ 35.52$ & $\$ 79.71$ & $\$ 44.18$ \\
\hline $\begin{array}{l}\text { High-Best- } \\
\text { Best }\end{array}$ & $\$ 30,277$ & 2,021 & $\$ 10,120$ & -675 & $\$ 20,157$ & 1,345 & 646 & $\$ 15.67$ & $\$ 46.89$ & $\$ 31.22$ \\
\hline $\begin{array}{l}\text { High-Low- } \\
\text { High }\end{array}$ & $\$ 51,462$ & 2,021 & $\$ 5,519$ & -217 & $\$ 45,943$ & 1,804 & 646 & $\$ 8.55$ & $\$ 79.71$ & $\$ 71.16$ \\
\hline $\begin{array}{l}\text { High-Low- } \\
\text { Low }\end{array}$ & $\$ 14,716$ & 2,021 & $\$ 1,578$ & -217 & $\$ 13,138$ & 1,804 & 646 & $\$ 2.44$ & $\$ 22.79$ & $\$ 20.35$ \\
\hline $\begin{array}{l}\text { Best-High- } \\
\text { High }\end{array}$ & $\$ 45,002$ & 1,767 & $\$ 20,194$ & -793 & $\$ 24,809$ & 974 & 565 & $\$ 35.77$ & $\$ 79.71$ & $\$ 43.94$ \\
\hline $\begin{array}{l}\text { Best-Best- } \\
\text { Best }\end{array}$ & $\$ 26,477$ & 1,767 & $\$ 8,916$ & -595 & $\$ 17,561$ & 1,172 & 565 & $\$ 15.79$ & $\$ 46.89$ & $\$ 31.10$ \\
\hline $\begin{array}{l}\text { Best-Low- } \\
\text { High }\end{array}$ & $\$ 45,002$ & 1,767 & $\$ 4,868$ & -191 & $\$ 40,135$ & 1,576 & 565 & $\$ 8.62$ & $\$ 79.71$ & $\$ 71.08$ \\
\hline $\begin{array}{l}\text { Best-Low- } \\
\text { Low }\end{array}$ & $\$ 12,869$ & 1,767 & $\$ 1,392$ & -191 & $\$ 11,477$ & 1,576 & 565 & $\$ 2.47$ & $\$ 22.79$ & $\$ 20.33$ \\
\hline $\begin{array}{l}\text { Low-High- } \\
\text { High }\end{array}$ & $\$ 36,212$ & 1,422 & $\$ 16,470$ & -647 & $\$ 19,742$ & 775 & 454 & $\$ 36.25$ & $\$ 79.71$ & $\$ 43.45$ \\
\hline $\begin{array}{l}\text { Low-Best- } \\
\text { Best }\end{array}$ & $\$ 21,305$ & 1,422 & $\$ 7,280$ & -486 & $\$ 14,024$ & 936 & 454 & $\$ 16.02$ & $\$ 46.89$ & $\$ 30.87$ \\
\hline $\begin{array}{l}\text { Low-Low- } \\
\text { High }\end{array}$ & $\$ 36,212$ & 1,422 & $\$ 3,983$ & -156 & $\$ 32,229$ & 1,266 & 454 & $\$ 8.77$ & $\$ 79.71$ & $\$ 70.94$ \\
\hline $\begin{array}{l}\text { Low-Low- } \\
\text { Low }\end{array}$ & $\$ 10,355$ & 1,422 & $\$ 1,139$ & -156 & $\$ 9,216$ & 1,266 & 454 & $\$ 2.51$ & $\$ 22.79$ & $\$ 20.29$ \\
\hline
\end{tabular}


Table 10 External Costs, by Scenarios BAU vs. METS - International Shipping, 2025

\begin{tabular}{|c|c|c|c|c|c|c|c|c|c|c|}
\hline \multicolumn{11}{|c|}{ International Shipping } \\
\hline \multirow{2}{*}{$\begin{array}{l}2025 \\
\text { Scenarios } \\
\text { GR-RR-P }\end{array}$} & \multicolumn{2}{|c|}{$\begin{array}{l}\text { BAU (Without } \\
\text { Reduction) }\end{array}$} & \multicolumn{2}{|c|}{ METS - Implemented } & \multicolumn{2}{|l|}{ Outcome } & \multirow[t]{2}{*}{$\begin{array}{l}F C \\
(M t)\end{array}$} & \multirow{2}{*}{$\begin{array}{l}\text { MAC } \\
\text { TAC/FC } \\
(\$ / t)\end{array}$} & \multirow{2}{*}{$\begin{array}{l}\text { MSC } \\
\text { (BAU) } \\
\text { TSC/FC } \\
(\$ / t)\end{array}$} & \multirow{2}{*}{$\begin{array}{l}\text { MSC } \\
\text { (METS) } \\
\text { TSC/FC } \\
(\$ / t)\end{array}$} \\
\hline & $\begin{array}{l}\text { TSC } \\
(\text { SM) }\end{array}$ & $\begin{array}{l}\mathrm{CO}_{2}^{-} \\
\text {Emitted } \\
\text { (Mt) }\end{array}$ & $\begin{array}{l}\text { TAC } \\
(\$ M)\end{array}$ & $\begin{array}{l}\mathrm{CO}_{2}- \\
\text { Abetment } \\
\text { (Mt) }\end{array}$ & $\begin{array}{l}\text { TD } \\
(\$ M)\end{array}$ & $\begin{array}{l}\mathrm{CO}_{2} \\
(\mathrm{Mt})\end{array}$ & & & & \\
\hline $\begin{array}{l}\text { High-High- } \\
\text { High }\end{array}$ & $\$ 71,520$ & 2,809 & $\$ 51,018$ & $-2,003$ & $\$ 20,502$ & 805 & 897 & $\$ 56.86$ & $\$ 79.71$ & $\$ 22.85$ \\
\hline $\begin{array}{l}\text { High-Best- } \\
\text { Best }\end{array}$ & $\$ 42,078$ & 2,809 & $\$ 24,112$ & $-1,609$ & $\$ 17,966$ & 1,199 & 897 & $\$ 26.87$ & $\$ 46.89$ & $\$ 20.02$ \\
\hline $\begin{array}{l}\text { High-Low- } \\
\text { High }\end{array}$ & $\$ 71,520$ & 2,809 & $\$ 17,859$ & -701 & $\$ 53,661$ & 2,107 & 897 & $\$ 19.90$ & $\$ 79.71$ & $\$ 59.80$ \\
\hline $\begin{array}{l}\text { High-Low- } \\
\text { Low }\end{array}$ & $\$ 20,452$ & 2,809 & $\$ 5,107$ & -701 & $\$ 15,345$ & 2,107 & 897 & $\$ 5.69$ & $\$ 22.79$ & $\$ 17.10$ \\
\hline $\begin{array}{l}\text { Best-High- } \\
\text { High }\end{array}$ & $\$ 60,002$ & 2,356 & $\$ 42,980$ & $-1,688$ & $\$ 17,022$ & 668 & 753 & $\$ 57.09$ & $\$ 79.71$ & $\$ 22.61$ \\
\hline $\begin{array}{l}\text { Best-Best- } \\
\text { Best }\end{array}$ & $\$ 35,301$ & 2,356 & $\$ 20,334$ & $-1,357$ & $\$ 14,968$ & 999 & 753 & $\$ 27.01$ & $\$ 46.89$ & $\$ 19.88$ \\
\hline $\begin{array}{l}\text { Best-Low- } \\
\text { High }\end{array}$ & $\$ 60,002$ & 2,356 & $\$ 15,087$ & -592 & $\$ 44,915$ & 1,764 & 753 & $\$ 20.04$ & $\$ 79.71$ & $\$ 59.66$ \\
\hline $\begin{array}{l}\text { Best-Low- } \\
\text { Low }\end{array}$ & $\$ 17,158$ & 2,356 & $\$ 4,314$ & -592 & $\$ 12,844$ & 1,764 & 753 & $\$ 5.73$ & $\$ 22.79$ & $\$ 17.06$ \\
\hline $\begin{array}{l}\text { Low-High- } \\
\text { High }\end{array}$ & $\$ 44,135$ & 1,733 & $\$ 31,923$ & $-1,254$ & $\$ 12,212$ & 480 & 554 & $\$ 57.65$ & $\$ 79.71$ & $\$ 22.05$ \\
\hline $\begin{array}{l}\text { Low-Best- } \\
\text { Best }\end{array}$ & $\$ 25,966$ & 1,733 & $\$ 15,137$ & $-1,010$ & $\$ 10,829$ & 723 & 554 & $\$ 27.34$ & $\$ 46.89$ & $\$ 19.56$ \\
\hline $\begin{array}{l}\text { Low-Low- } \\
\text { High }\end{array}$ & $\$ 44,135$ & 1,733 & $\$ 11,277$ & -443 & $\$ 32,858$ & 1,290 & 554 & $\$ 20.37$ & $\$ 79.71$ & $\$ 59.34$ \\
\hline $\begin{array}{l}\text { Low-Low- } \\
\text { Low }\end{array}$ & $\$ 12,621$ & 1,733 & $\$ 3,225$ & -443 & $\$ 9,396$ & 1,290 & 554 & $\$ 5.82$ & $\$ 22.79$ & $\$ 16.97$ \\
\hline
\end{tabular}


Table 11 External Costs, by Scenarios BAU vs. METS - International Shipping, 2030

\begin{tabular}{|c|c|c|c|c|c|c|c|c|c|c|}
\hline \multicolumn{11}{|c|}{ International Shipping } \\
\hline \multirow{2}{*}{$\begin{array}{l}2030 \\
\text { Scenarios } \\
\text { GR-RR-P }\end{array}$} & \multicolumn{2}{|c|}{$\begin{array}{l}\text { BAU (Without } \\
\text { Reduction) }\end{array}$} & \multicolumn{2}{|c|}{ METS - Implemented } & \multicolumn{2}{|c|}{ Outcome } & \multirow[t]{2}{*}{$\begin{array}{l}\mathrm{FC} \\
(\mathrm{Mt})\end{array}$} & \multirow{2}{*}{$\begin{array}{l}\text { MAC } \\
\text { TAC/FC } \\
(\$ / t)\end{array}$} & \multirow{2}{*}{$\begin{array}{l}\text { MSC } \\
\text { (BAU) } \\
\text { TSC/FC } \\
(\$ / t)\end{array}$} & \multirow{2}{*}{$\begin{array}{l}\text { MSC } \\
\text { (METS) } \\
\text { TSC/FC } \\
(\$ / t)\end{array}$} \\
\hline & $\begin{array}{l}\text { TSC } \\
(\text { SM) }\end{array}$ & $\begin{array}{l}\mathrm{CO}_{2} \text { - } \\
\text { Emitted } \\
\text { (Mt) }\end{array}$ & $\begin{array}{l}\text { TAC } \\
(\$ M)\end{array}$ & $\begin{array}{l}\mathrm{CO}_{2}- \\
\text { Abetment } \\
\text { (Mt) }\end{array}$ & $\begin{array}{l}\text { TD } \\
(\$ M)\end{array}$ & $\begin{array}{l}\mathrm{CO}_{2} \\
(\mathrm{Mt})\end{array}$ & & & & \\
\hline $\begin{array}{l}\text { High-High- } \\
\text { High }\end{array}$ & $\$ 99,596$ & 3,911 & $\$ 92,058$ & $-3,615$ & $\$ 7,538$ & 296 & 1250 & $\$ 73.67$ & $\$ 79.71$ & $\$ 6.03$ \\
\hline $\begin{array}{l}\text { High-Best- } \\
\text { Best }\end{array}$ & $\$ 58,596$ & 3,911 & $\$ 48,071$ & $-3,209$ & $\$ 10,525$ & 703 & 1250 & $\$ 38.47$ & $\$ 46.89$ & $\$ 8.42$ \\
\hline $\begin{array}{l}\text { High-Low- } \\
\text { High }\end{array}$ & $\$ 99,596$ & 3,911 & $\$ 53,867$ & $-2,115$ & $\$ 45,729$ & 1,796 & 1250 & $\$ 43.11$ & $\$ 79.71$ & $\$ 36.60$ \\
\hline $\begin{array}{l}\text { High-Low- } \\
\text { Low }\end{array}$ & $\$ 28,481$ & 3,911 & $\$ 15,404$ & $-2,115$ & $\$ 13,077$ & 1,796 & 1250 & $\$ 12.33$ & $\$ 22.79$ & $\$ 10.47$ \\
\hline $\begin{array}{l}\text { Best-High- } \\
\text { High }\end{array}$ & $\$ 80,572$ & 3,164 & $\$ 74,589$ & $-2,929$ & $\$ 5,983$ & 235 & 1011 & $\$ 73.79$ & $\$ 79.71$ & $\$ 5.92$ \\
\hline $\begin{array}{l}\text { Best-Best- } \\
\text { Best }\end{array}$ & $\$ 47,403$ & 3,164 & $\$ 38,994$ & $-2,603$ & $\$ 8,410$ & 561 & 1011 & $\$ 38.57$ & $\$ 46.89$ & $\$ 8.32$ \\
\hline $\begin{array}{l}\text { Best-Low- } \\
\text { High }\end{array}$ & $\$ 80,572$ & 3,164 & $\$ 43,782$ & $-1,719$ & $\$ 36,789$ & 1,445 & 1011 & $\$ 43.31$ & $\$ 79.71$ & $\$ 36.39$ \\
\hline $\begin{array}{l}\text { Best-Low- } \\
\text { Low }\end{array}$ & $\$ 23,040$ & 3,164 & $\$ 12,520$ & $-1,719$ & $\$ 10,520$ & 1,445 & 1011 & $\$ 12.39$ & $\$ 22.79$ & $\$ 10.41$ \\
\hline $\begin{array}{l}\text { Low-High- } \\
\text { High }\end{array}$ & $\$ 54,011$ & 2,121 & $\$ 50,217$ & $-1,972$ & $\$ 3,795$ & 149 & 678 & $\$ 74.11$ & $\$ 79.71$ & $\$ 5.60$ \\
\hline $\begin{array}{l}\text { Low-Best- } \\
\text { Best }\end{array}$ & $\$ 31,777$ & 2,121 & $\$ 26,335$ & $-1,758$ & $\$ 5,442$ & 363 & 678 & $\$ 38.86$ & $\$ 46.89$ & $\$ 8.03$ \\
\hline $\begin{array}{l}\text { Low-Low- } \\
\text { High }\end{array}$ & $\$ 54,011$ & 2,121 & $\$ 29,730$ & $-1,167$ & $\$ 24,282$ & 954 & 678 & $\$ 43.87$ & $\$ 79.71$ & $\$ 35.83$ \\
\hline $\begin{array}{l}\text { Low-Low- } \\
\text { Low }\end{array}$ & $\$ 15,445$ & 2,121 & $\$ 8,501$ & $-1,167$ & $\$ 6,944$ & 954 & 678 & $\$ 12.55$ & $\$ 22.79$ & $\$ 10.25$ \\
\hline
\end{tabular}




\section{Abbreviations}

BAU, business as usual; CO2, carbon dioxide; CRSL, Clarkson Research Services Limited; EEDI, energy efficiency design index; EEOI, energy efficiency operational index; EPA, environmental protection agency; ETS, emission trade scheme; EUA, emission unit allowance; EU-ETS, European Union Emission Trade Scheme; FC, fuel consumption; GDP, gross domestic product; GHG, greenhouse emission; HFO, heavy fuel oil; ICF, International Compensation Fund; IHS-GI, IHSGlobal Insight; IMF, International Monetary Found; IMO, International Maritime Organization; IPCC, Intergovernmental Panel on Climate Change; ISC, Indian Sub-Continent; LBG, liquefied biogas; LMIU, Lloyd's Marine Intelligence Unit; LNG, liquefied natural gas; MEPC, Marine Environment Protection Committee; METS, marine emission trading scheme; PPP, purchasing power parity; RFO, residual fuel oil; SEEMP, Ship Energy Efficiency Management Plan; UNCTAD, United Nations Conference on Trade and Development

\section{Authors' contributions}

EB conceived of the study, carried out the economic review and performed the statistical analysis, results and contribution. MS \& YH participated in the design of the study and helped to draft the manuscript. All authors read and approved the final manuscript.

\section{Competing interests}

The author(s) declare that they have no competing interests.

\section{Author details}

${ }^{1}$ Faculty of Industrial Engineering and Management, Technion - Israel Institute of Technology, Haifa, Israel. ${ }^{2}$ Natural Resources and Environmental Research Center (NRERC), University of Haifa, Haifa, Israel. ${ }^{3}$ Samuel Neaman Institute, Technion - Israel Institute of Technology, Haifa, Israel.

Received: 7 October 2015 Accepted: 8 June 2016

Published online: 20 July 2016

\section{References}

Bazari Z, Longva T (2011) Assessment of IMO Mandated Energy Efficiency Measures for International Shipping, International Maritime Organization, London, UK.

Ben-Hakoun E, Shechter M, Hayuth Y (2015) Economic Evaluation of the Environmental Impact of Shipping from the Perspective of CO2 Emissions - WCTRS-Sig2 Conference Paper. In. Economic Evaluation of the Environmental Impact of Shipping from the Perspective of CO2 Emissions Conference Paper. Technion city, Haifa. Retrieved (http://uahost.uantwerpen.be/sig2/wctrs/papers2015/ben-hakoun.pdf). Access 15 Feb 2016

Branger F, Lecuyer O, Quirion P (2013) The European Union Emissions Trading System: Should We Throw the Flagship out with the Bathwater? France. Retrieved February 15, 2014 (http://www.centre-cired.fr/IMG/pdf/CIREDWP-201348.pdf)

Brynolf S, Fridell E, Andersson K (2014) Environmental assessment of marine fuels: liquefied natural gas, liquefied biogas, methanol and bio-methanol. J Clean Prod 74(X):86-95

Buhaug $\varnothing$. et al. (2009) Second IMO GHG Study, 2009. International Maritime Organization (IMO). In: Buhaug Ø, Corbett JJ, Endresen $\varnothing$, Eyring V, Faber J, Hanayama S, Lee DS, Lee D, Lindstad and K, Markowska AZ, Mjelde A, Nelissen D, Nilsen J, Pålsson C, Winebrake JJ, Wu W, Yoshida. London, UK. Retrieved November 4, 2012 (http://www.imo.org/blast/ mainframe.asp?topic_id=231)

Buhaug Ø. et al. (2009) Second IMO GHG Study, 2009. International Maritime. Organization (IMO). edited by H. Buhaug $\varnothing$, Corbett JJ, Endresen $\varnothing$, Eyring V, Faber J, Hanayama S, Lee DS, Lee D, Lindstad and K. Markowska AZ, Mjelde A, Nelissen D, Nilsen J, Pålsson C, Winebrake JJ, Wu W, Yoshida. London, UK. Retrieved November 4, 2012. (http:// www.imo.org/en/OurWork/Environment/PollutionPrevention/AirPollutio.n/Documents/GHGStudyFINAL.pdf)

Coase RH (1960) The problem of social cost. Libr Crit Writ Econ 3(October):1-28, Retrieved March 19, 2013 (http://www2.econ.iastate.edu/classes/tsc220/hallam/Coase.pdf)

Corbett JJ et al (2007) Mortality from ship emissions: a global assessment. Environ Sci Technol 41(24):8512-8518, Retrieved (http://www.ncbi.nlm.nih.gov/pubmed/18200887)

Corbett JJ, Firestone J, Wang C (2007) Estimation, Validation, and Forecasts of Regional Commercial Marine Vessel Inventories Final Report. California Air Resources Board, California Environmental Protection Agency and Commission for Environmental Cooperation of North America. (http://www.arb.ca.gov/research/seca/jcfinal.pdf)

Crocker TD (1966) The structuring of atmospheric pollution control systems. In: Wolozin H (ed) The economics of air pollution. H. Wolozin. New York, W. W.Norton \& Co.: 61-86

Dales JH (1968) Pollution, Property and Prices. Toronto, University of Toronto Press

Eide MS (2009) Update on Emissions and Environmental Impacts from the International Fleet of Ships: The Contribution from Major Ship Types and Ports. Atmospheric. Retrieved June 18, 2012 (http://www.atmos-chemphys-discuss.net/8/18323/2008/acpd-8-18323-2008.pdf)

EnSys Energy \& Systems Inc. and Navigistics Consulting, API (2007) Analysis of Impacts on Global Refining \& CO2 Emissions of Potential MARPOL Regulations for International Marine Bunker Fuels, Final Report. Lexington, MA

Eyring V, Corbett J, Lee D, Winebrake J (2007) Brief summary of the impact of ship emissions on atmospheric composition, climate, and human health. Document submitted to the Health and Environment sub-group of the International Maritime Organization, 6 November 2007

Fisher I (1930) The Theory of Interest. The Macmillan Co (ed). New York: Library of Economics and Liberty. Retrieved (http://www.econlib.org/library/YPDBooks/Fisher/fshTol.html)

Foster V, Hahn RW (1995) Designing more efficient markets: lessons from Los Angeles smog control. J Law Econ 38(1):19-48, Retrieved (http://dx.doi.org/10.1086/467324)

Freeman J, Kolstad CD (2007) Moving to markets in environmental regulation: Lessons from twenty years of experience. Oxford University Press, Oxford 
Goulder LH (2013) Markets for pollution allowances: what are the (New) lessons? J Econ Perspect 27(1):87-102, Retrieved (http://www.jstor.org/stable/41825463)

Hahn RW, Hester GL (1989) Marketable permits: lessons for theory and practice. Ecol Law Quart 16(18):361-406, Retrieved (http://scholarship.law.berkeley.edu/elq/vol16/iss2/1)

Hassellöv IM, Turner DR, Lauer A, Corbett JJ (2013) Shipping contributes to ocean acidification. Geophys Res Lett 40(11): 2731-2736, Retrieved October 22, 2013 (http://doi.wiley.com/10.1002/grl.50521)

IMO MEPC 59/24, International Maritime Organization (2009) 2009 Guidelines for port state control under the revised MARPOL ANNEX VI. London, UK. Retrieved (http://www.imo.org/blast/mainframe.asp?topic_id=231)

IMO MEPC 60/4/22, International Maritime Organization (2010) Prevention of Air Pollution from Ships - A Further Outline of a Global Emission Trading System (ETS) for International Shipping. (Norway). London, United Kingdom. Retrieved February 15, 2014 (http://www.rina.org.uk/c2/uploads/mepc\%2060_4_22.pdf)

IMO MEPC 63/INF.2, 2011 (http://www.imo.org/en/OurWork/Environment/PollutionPrevention/AirPollution/Documents/ Technical\%20and\%200perational\%20Measures/INF-2.pdf)

IPCC, Intergovernmental Panel on Climate Change (2007) Climate Change 2007: Synthesis Report. Contribution of Working Groups I, II and III to the Fourth Assessment Report of the Intergovernmental Panel on Climate Change. In: Core Writing Team, Pachauri R K, Reisinger A (eds). Geneva, Switzerland

Laing T, Sato M, Grubb M, Comberti M (2013) Assessing the Effectiveness of the EU Emissions Trading System. London, UK. Retrieved (http://www.lse.ac.uk/GranthamInstitute/wp-content/uploads/2014/02/WP106-effectiveness-euemissions-trading-system.pdf). Access 15 Feb 2014

Marine Environment Protection Committee [MEPC] (2011) Closing remarks by the Secretary-General Eftimios E. Mitropoulos at the ending of the $62^{\text {nd }}$ session of the Marine. Environment Protection Committee (11 to 15) July 2011)

Montgomery WD (1972) Markets in licenses and efficient pollution control programs. J Econ Theory 5(3):395-418, Retrieved February 13, 2014 (http://www.sciencedirect.com/science/article/pii/002205317290049X). doi:10.1016/0022-0531(72)90049-X

Tietenberg TH (1985) Emissions trading, an exercise in reforming pollution policy. Land Econ 62(2):214-216, Retrieved (http://www.jstor.org/stable/3146340). Access 1 June 2012

Tietenberg T (2006) Tradable permits in principle and practice. In: Moving to markets in environmental regulation: lessons from twenty years of experience

UNCTAD, United Nations Conference on Trade and Development (2011) Review of Maritime Transport. New York and Geneva: United Nations Conference on Trade and Development; United Nations Publications. Retrieved October 22, 2013 (http://trid.trb.org/view.aspx?id=1134246)

UNFCCC, United Nations Framework Convention on Climate Change (2009) "Shipping, World Trade and the Reduction of co2 Emissions." 6. Retrieved (http://www.ics-shipping.org/docs/co2)

Weitzman ML (1974) Prices vs. Quantities. Rev Econ Stud Wiley Blackwell 41(4):477-491

Submit your manuscript to a SpringerOpen ${ }^{\circ}$ journal and benefit from:

- Convenient online submission

- Rigorous peer review

- Immediate publication on acceptance

- Open access: articles freely available online

- High visibility within the field

- Retaining the copyright to your article

Submit your next manuscript at $\boldsymbol{~ s p r i n g e r o p e n . c o m ~}$ 